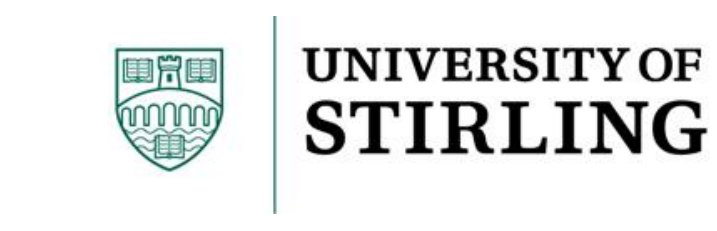

Stirling Management School

\title{
Youth Unemployment: Déjà Vu?
}

David N.F. Bell

David G. Blanchflower

Stirling Economics Discussion Paper 2010-04

January 2010

Online at http://www.economics.stir.ac.uk 


\title{
Youth Unemployment: Déjà $\mathrm{Vu}$ ?
}

\author{
David N.F. Bell
}

Division of Economics

Stirling Management School, University of Stirling and IZA

and

\section{David G. Blanchflower}

Bruce V. Rauner Professor of Economics, Department of Economics, Dartmouth College,

Division of Economics, Stirling Management School, University of Stirling

IZA, CESifo and NBER

\begin{abstract}
:
This paper reviews current issues in youth labour markets in developed countries. It argues that young people aged 16-25 have been particularly hard hit during the current recession. Using the USA and UK as cast studies, it analyses both causes and effects of youth unemployment using micro-data. It argues that there is convincing evidence that the young are particularly susceptible to the negative effects of spells of unemployment well after their initial experience of worklessness. Because the current youth cohort is relatively large, the longer-term outlook for youth unemployment is quite good, but there is a strong case for policy intervention now to address the difficulties that the current cohort is having in finding access to work.
\end{abstract}

JEL Codes: J01, J11, J21, J23, J38, J64

Keywords: Youth unemployment, recession, wages, well-being, economic policy

Corresponding author: David Bell, Division of Economics, University of Stirling, Stirling, Scotland, UK, dnfb1@stir.ac.uk 


\section{Introduction}

Youth unemployment is one of the most pressing economic and social problems confronting those countries whose labor markets have weakened substantially since 2008, following the near-collapse of worldwide financial markets. There is an element of déjà $\mathrm{vu}$ around this development: youth unemployment first became a serious problem for industrialized countries during the 1980s. While labour markets were booming in the early part of this century, youth unemployment was still a concern. But the particularly rapid increase in youth unemployment during the current recession has once again sharpened the policy focus on this issue.

The overall increase in unemployment has been dramatic: the October 2009 IMF in its World Economic Outlook, 2009, suggests that the unemployment rate in advanced economies will rise from 5.4 per cent in 2007 to 9.3 per cent in 2010. The IMF expects this number to peak at over ten per cent. ${ }^{1}$ The OECD in its Economic Outlook, 86, November 2009, forecasts that the OECD unemployment rate will be $9.8 \%$ in $2010 .^{2}$ The OECD generally is less optimistic about how high unemployment rates will increase than the IMF.

This paper focuses particularly on youth unemployment, why we should be concerned about it, why it is increasing again, how the present difficulties of young people entering the labour market differ from those of the past and what useful lessons have been learned that may guide future policy on youth unemployment. We focus mainly on the UK and USA, but introduce evidence from other countries where appropriate. The youth joblessness crisis of the early 1980s appears to be repeating itself. It feels like déjà vu.

\section{Youth labour markets}

Table 1 reports how OECD countries have been impacted by the recession. We report the turning point of the recession, measured by the low point of the unemployment rate and the extent to which the unemployment rate has increased since then. Spain, Ireland and the United States have had the largest increases in unemployment. Germany and the Netherlands have had the smallest increases.

\footnotetext{
${ }^{1}$ The IMF forecasts unemployment in 2010 will be as follows: advanced economies $9.3 \%$; United States 10.1\%; Euro area1 11.7\%; Germany $10.7 \%$; France $10.3 \%$; Italy $10.5 \%$; Spain $20.2 \%$; Netherlands $6.6 \%$; Belgium 9.9\%; Greece 10.5\%; Austria 6.4\%; Portugal 11.0\%; Finland 9.8\%; Ireland 15.5\%; Slovak Republic 10.3\%; Slovenia 6.1\%; Luxembourg 6.0\%; Cyprus 5.9\%; Malta 7.6\%; Japan 6.1\%; United Kingdom1 9.3\%; Canada 8.6\%; Korea 3.6\%; Australia 7.0\%; Taiwan 5.9\%; Sweden 8.2\%; Switzerland 4.5\%; Hong Kong 6.5\%; Czech Republic 9.8\%; Norway 3.8\%; Singapore 3.7\%; Denmark 4.2\%; Israel 8.6\%; New Zealand 7.9\%; Iceland 10.5\%; major advanced economies $9.4 \%$ and newly industrialized Asian economies $4.4 \%$;

${ }^{2}$ The OECD forecast for unemployment rates in 2010 by country is as follows: Australia 7.7\%; Austria 7.9\%; Belgium 10.6\%; Canada 9.8\%; Czech Republic 9.2\%; Denmark 7.9\%; Finland 10.8\%; France 11.2\%; Germany $11.6 \%$; Greece $10.3 \%$; Hungary $11.7 \%$; Iceland 9.9\%; Ireland $14.8 \%$; Italy 10.2\%; Japan 5.7\%; Korea 3.9\%; Luxembourg 7.2\%; Mexico1 6.9\%; Netherlands 7.0\%; New Zealand 7.9\%; Norway 4.3\%; Poland 11.6\%; Portugal 11.2\%; Slovak Republic 13.6\%; Spain 19.6\%; Sweden 11.4\%; Switzerland 5.1\%; Turkey 16.4\%; United Kingdom 9.7\%; United States 10.1\%; Euro area $12.0 \%$ and Total OECD $9.8 \%$.
} 
The young, have been particularly affected, by the rising levels of unemployment associated with this recession, in Europe and North America. Table 2 shows the rise in youth unemployment rates from July 2008 to July 2009. Currently youth unemployment rates for the under $25 \mathrm{~s}$ in the EU27 are $19.7 \%$ and $17.8 \%$ in the United States respectively. They are especially high in Spain (38.4\%). They are everywhere higher than adult rates. The final column gives the ratio of youth to overall unemployment rates. Youth rates are more than two and a half times overall rates in Belgium, Finland, France, Hungary, Luxembourg, Slovenia, Sweden and the UK.

In 2008, the $\mathrm{ILO}^{3}$ noted that recently there had been a declining trend in youth unemployment around the world. The world unemployment rate of youth aged 15-24 rose from $10.9 \%$ in 1999 to a peak in 2004 of $12.6 \%$ and declined to 11.9 per cent by 2007 (Table 3). The ILO noted that the world youth unemployment rate was nearly three times the adult rate but 2.4 times in the developed world. It is apparent that, in contrast to the rest of the world, the trend in youth unemployment has been rising in the UK, as has the ratio of youth-to-adult rates.

The United Nations (2007) confirmed the finding of high youth unemployment rates and high youth-to-adult rates in the UK. ${ }^{4}$ They estimated this ratio in the UK at 3.6 in 2005, which, in Europe was only exceeded by Malta (3.7), Italy (3.9), Sweden (3.8) and Iceland (4.5) and joint sixteenth with Costa Rica and Haiti out of 117 countries. Outside Europe, New Zealand was the only OECD country with a higher ratio (3.8).

The proportion of the young in the UK who are in full-time education, increased from $26 \%$ in 1993 to $38 \%$ in 2007 . This proportion is still well below that of many other countries. Data from the OECD suggests that the proportion of the young who are in school is considerably higher in, for example, Belgium (60\%); Finland (56\%); France (61\%), Italy (57\%); Luxembourg (69\%) and Sweden $(57 \%)$. One response to rising unemployment on the part of youth has been to return to full-time education (Blanchflower and Freeman, 2000, Rice, 1999). ${ }^{5}$

One effect of the increased participation in further education is that the 16-24 cohort, are now better qualified than they were during the last recession. Thus, for example, in 1993, 5.8 per cent of 16-24 year olds were graduates, while in 2008 that share had risen to 13.2 per cent. The improvement in qualifications is more concentrated among females than males. By 2008, the proportion of females aged 18-24 with no qualifications had fallen to 4.6 per cent, but for males was still over 7 per cent. Reflecting the generally higher skills profile among females, it is also worth noting that mean hourly wages for females are

\footnotetext{
3 ILO (2008), 'Global employment trends for youth', October, ILO Geneva.

${ }^{4}$ United Nations (2007), 'The world youth report 2007-young people's transition to adulthood: progress and challenges', United Nations (http://www.un.org/esa/socdev/unyin/documents/wyr07_complete.pdf).

${ }^{5}$ P. Rice (1999), 'The impact of local labour markets on investment in higher education: evidence from the England and Wales Youth Cohort Studies', Journal of Population Economics, 12, pp. 287-312.
} 
higher than those for males among this age group, though not significantly so (Source: Labour Force Survey).

The OECD (2008b) recently also noted that, even before the slowing of the UK labour market in the spring of 2008, a variety of indicators of youth performance between 2005 and 2007 do paint a more mixed picture. ${ }^{6}$ On the one hand, they noted that the youth employment rate is 12 percentage points higher than the OECD average and long-term unemployment has decreased by over 7 percentage points over the past decade. The young in the UK are less likely to be in temporary work but more likely to be part-time than in the OECD as a whole. Dropout rates continue to be below the OECD average. Low-paid employment is still common among youth but its persistence has halved since the early 1990 s..

There is also some evidence from around the world, that the least educated, as well as those with the lowest skill levels, plus minorities and immigrants, are especially impacted by the drop in demand. In the US for example, in August 2009, black unemployment rates stood at $15.1 \%$ and Hispanics at $13.0 \%$ compared with $8.9 \%$ for whites. Unemployment rates for high school dropouts were $15.6 \%$ compared with $9.7 \%$ for high school graduates, $8.2 \%$ for those with some college and $4.7 \%$ for those with a college degree and higher.

In the UK, unemployment rates are much higher for the least skilled occupations. According to weighted data from the recently available UK 2009 Q2 Labour Force Survey (LFS), unemployment rates by highest qualification were as follows.

$\begin{array}{lr}\text { Degree or equivalent } & 3.7 \% \\ \text { Higher degree } & 2.7 \% \\ \text { First degree } & 3.8 \% \\ \text { Other degree } & 3.3 \% \\ \text { Higher education } & 4.2 \% \\ \text { GCE A level or equivalent } & 7.3 \% \\ \text { GCSE grades A-C or equivalent } & 9.6 \% \\ \text { Other qualifications } & 10.7 \% \\ \text { No qualifications } & 14.4 \%\end{array}$

Unemployment rates, which average $7.7 \%$, by racial group were whites $7.1 \%$, mixed race 17.2\%; Asians $11.8 \%$, blacks $17.3 \%$ and Chinese $4.2 \%$. The unemployment rate of those whose country of origin was outside the UK was $9.3 \%$. According to the Eurobarometer survey of individuals available \#70.1, which surveyed respondents in the EU27 between October and November 2008, the weighted EU27 average unemployment rates by education attainment suggested unemployment rates of $4.7 \%$ for individuals who left

\footnotetext{
${ }^{6}$ OECD (2008b), Jobs for Youth - United Kingdom, OECD, Paris

${ }^{7}$ Source: 'The employment situation', Bureau of Labor Statistics, August 2009. http://www.bls.gov/news.release/empsit.nr0.htm
} 
school at age 20 or higher and $9.0 \%$ for those who left school at a younger age. ${ }^{8}$ Unemployment rates were $7.6 \%$ for the indigenous populations and $11.1 \%$ for immigrants. Table 4 provides evidence of unemployment rates by qualification across OECD countries. It is quite clear that for all age groups and countries, unemployment rates are higher for the least educated.

We now turn to examine very recent micro-data on unemployment in Europe, for Spring 2009. In Table 5, we make use of the data from Eurobarometer \#71.2, which was taken in May-June in the EU27 countries plus Croatia, Macedonia and Turkey. In total there are nearly 30,000 observations. In column 1 we estimate a dprobit on the probability an individual is unemployed, zero otherwise. ${ }^{9}$ The proportion of the total population that are under the age of twenty five are two and a half percentage points higher than those aged 45-54 and lower than those aged 25-34. In part this arises because of the high proportion of youngsters who are still studying. However, in column two, when the sample is conditioned on being a member of the labour force, it is apparent that the unemployment rate of the young is especially high. Unemployment is highest for the least educated, minorities, those suffering from a chronic physical or mental health problem which affects their daily activities and residents of Spain, Ireland, Croatia, East Germany, Hungary, Latvia, Lithuania and Macedonia.

Column 3 estimates the probability that the respondent reports that they have lost a job of the result of the economic crisis. The sample again includes the whole population and once more the young are disproportionately hard hit. Men, the least educated, and residents of Ireland, Latvia, Lithuania and Spain are most likely to report in the affirmative.

Of interest also are the attitudes of the young employed to the possibility that they will lose their job in the near term, and also if they did how hard it would be for them to find another one. Column 4 estimates an ordered logit where the employed are asked how confident they are in their 'ability to keep their job over the next few months'. The young are especially confident. The result is similar in column 5 which models the likelihood a worker could find a job if laid-off on a ten point scale where 1 is not at all likely and 10 is very likely. The old, immigrants and the unhealthy are especially fearful of finding another job. The young are especially optimistic that they could find a job if they were laid-off.

Table 6 provides some explanation for the rise in youth unemployment. The youth cohort is especially large at a time when the labor market is in the doldrums. The table shows the size of four single age cohorts in comparison to the size of the cohort of twenty

\footnotetext{
${ }^{8}$ Data are available on approximately 25,000 individuals in the workforce.

${ }^{9}$ Dprobit fits maximum-likelihood probit models and is an alternative to probit. Rather than reporting the coefficients, dprobit reports the marginal effect, that is the change in the probability for an infinitesimal change in each independent, continuous variable and, by default, reports the discrete change in the probability for dummy variables.
} 
year olds, which for simplicity is set to 100. In some countries twenty five year olds are the largest group while for others, the maximum occurs at a different age. We find that

a) In some Western countries the number of twenty year olds is greater than the number of twenty five year olds. Examples are the UK, Sweden, the Netherlands, Italy and Denmark that have very high youth unemployment rates.

b) Significant exceptions to this finding are evident in Eastern Europe (Armenia, Belarus, Estonia, Georgia, Latvia, Lithuania, Moldova, Romania, Russia and the Ukraine) that have declining birth rates and hence aging populations.

c) The size of the youth cohort will quickly collapse, especially in Eastern Europe.

Over the next five years, based on the current number of fifteen year olds, there will be a rapid decline in the number of twenty year olds. Progressively shrinking cohorts will have even more dramatic effects on the number of entrants to the labour market in ten and fifteen years time. The decline is relatively small in the US compared with other countries, in part because of its relatively high rate of immigration. Immigrants tend to be young. In ten years time in the Euro area the number of twenty year olds will have dropped by twelve percent. In ten years, the size of the youth cohort is going to be smaller in all European countries except Denmark, Luxembourg and Norway.

In summary, the recession has reversed recent reductions in youth unemployment in the developed world. Like other groups on the margins of the labour market, the young tend to experience particularly high rates of unemployment during recessions. The current experience fits this pattern. However, the youth cohort is diminishing in size in most countries, suggesting that, in the future, excess supply of younger workers is less likely to be problematic.

\section{Two Case studies - the United States and the United Kingdom}

In this section, we investigate past and current labour market experience for younger people using two large scale, micro-datasets workers in two countries - the United States and the United Kingdom.

a) The youth labor market in the United States.

A great deal of what is known about the youth labor market comes from a series of research volumes published by the National Bureau of Economic Research. These volumes were based primarily, but not exclusively on research done in the United States (Freeman and Wise, 1982; Blanchflower and Freeman, 2000). ${ }^{10}$ It is certainly a case of

\footnotetext{
${ }^{10}$ Freeman, R. B. and D. A. Wise, (editors), The Youth Labor Market Problem: Its Nature, Causes, and Consequences, University of Chicago Press and NBER. R.B. Freeman and H. J. Holzer, 'The Black Youth Employment Crisis', University of Chicago Press and NBER, 1986 D.G. Blanchflower and R.B. Freeman (editors), Youth Employment and Joblessness in Advanced Countries, University of Chicago Press and NBER, 2000
} 
déjà $v u$ in the United States, where the youth labour market crisis that occurred in the 1980 s is now repeating itself.

As mentioned above, the size of the youth cohort in the US is not going to decline as fast as in most other OECD countries, as was apparent from Table 6, partly due to immigration. Immigrants tend to disproportionately be young and have more children. Figure 1 illustrates.

Table 7 presents recent evidence on changes in labour market status of young people ages 16-24 in July of each year from 2006 to 2009. The youth labor force aged 16 to 24 working or actively looking for work grows sharply between April and July each year. During these months, large numbers of high school and college students take or search for summer jobs, and many graduates enter the labor market to look for, or begin, permanent employment. In the summer of 2009, the youth labor force grew by 2.6 million to a total of 23.7 million. Consistent data are available for four years. A number of findings stand out

1) Youth unemployment has grown rapidly in both levels and rates since 2007. At the same time labour force participation rates and employment-population rates fell. Most rapid growth was in youngsters looking for full-time jobs.

2) Unemployment rates were especially high for blacks (31.2\% in 2009) and Hispanics $(21.7 \%)$.

3) Unemployment rates were higher for men than women.

Table 8 pursues further the issue of the characteristics of the young unemployed and how these have changed over time in the United States. It reports the results of estimating a dprobit where the dependent variable is one if the individual is unemployed, zero if employed. Columns 1-3 make use of data from the Outgoing Rotation Group files of the Current Population Survey for 1979; 1982-1983 pooled; 2007 and 2008 pooled. The final column for 2009 makes use of data from the Basic Monthly files of the CPS, of which the outgoing rotation group files are a subset. We choose these years to compare the incidence of youth unemployment in this recession with that of the early 1980s. In 1979 the annual unemployment rate was 5.8\% compared $9.7 \%$ in 1982 and $9.6 \%$ in 1983. In 2007 it was $4.6 \%$ and 5.8\% in 2008: it averaged 9\% from January-September 2009. Hence we can compare the changes that took place as the labour market went from boom to bust in both recessions.

The raw data for the young are as follows. From boom to bust in both recessions impacts the least educated, African Americans and especially African Americans who are high school dropouts. This is confirmed in the regressions. 


\begin{tabular}{lcccr}
\multicolumn{2}{c}{ US Unemployment rates \% (weighted) } & & & \\
& White & Black & Hispanic & All \\
1979 & 9.9 & 26.3 & 13.3 & 11.9 \\
High school dropout & 17.5 & 36.4 & 18.4 & 19.9 \\
1982-1983 & 14.8 & 36.8 & 21.9 & 17.8 \\
High school dropout & 25.9 & 53.1 & 31.8 & 29.7 \\
Some college & 9.0 & 26.9 & 12.2 & 10.8 \\
2007-2008 & 9.6 & 19.6 & 12.3 & 11.3 \\
High school dropout & 16.8 & 31.6 & 17.1 & 18.8 \\
2009 & 15.0 & 28.4 & 19.2 & 17.6 \\
High school dropout & 23.8 & 43.6 & 26.5 & 27.2 \\
Some college & 9.5 & 18.6 & 12.6 & 11.2
\end{tabular}

The probability of being unemployed is highest for those aged 16. Young blacks are especially hard hit by recession. But up to 2009, the gap between whites and blacks in terms of their relative unemployment rates is much less than in the $80 \mathrm{~s}$.

\section{b) The nature of the youth labour market problem in the UK}

The majority of youth unemployment in the UK is in the 18-24 age group (the young), rather than in the 16-17 age group (the very young). For example, in 2009 Q3 there were 197,000 unemployed 16 and 17 year olds compared with 746,000 18-24 year olds. There were half a million claimants of unemployment benefits, who were aged 18-24, but none who were 16-17, as this age group is not eligible to claim unemployment benefits. The representation of those aged less than 25 among the unemployed is much greater than their representation in the overall population. ${ }^{11}$

Those unemployed aged 18-24 have increased as a share of total unemployment since the turn of the millennium. As can be seen below, despite a declining overall unemployment rate and a declining rate for the young between 1993 and 2004, their unemployment rate has risen since then. Moreover, their share of unemployment has risen steadily from $21.7 \%$ in 1999 to $31.4 \%$ in 2008 but has fallen back a little at the end of 2009.

\footnotetext{
${ }^{11}$ In 2007 15-24 year olds constituted $13.37 \%$ of the population and $20.15 \%$ of the population of working age (15-64M/59F). See Table 1.4 Population Trends, No 134, Winter 2008. http://www.statistics.gov.uk/StatBase/Product.asp?vlnk=6303
} 


\begin{tabular}{lrrr} 
Unemployment rate & \multicolumn{1}{c}{$18-24$ unemployment rate } & $18-24$ as \% overall \\
1993 & 10.4 & 17.5 & 25.0 \\
1994 & 9.5 & 16.3 & 23.9 \\
1995 & 8.6 & 15.0 & 23.1 \\
1996 & 8.1 & 14.3 & 22.7 \\
1997 & 6.9 & 12.9 & 22.3 \\
1998 & 6.3 & 12.0 & 22.8 \\
1999 & 6.0 & 11.2 & 21.7 \\
2000 & 5.4 & 10.6 & 22.4 \\
2001 & 5.1 & 10.4 & 23.9 \\
2002 & 5.2 & 10.5 & 23.8 \\
2003 & 5.1 & 10.6 & 24.8 \\
2004 & 4.8 & 10.4 & 26.2 \\
2005 & 4.9 & 11.0 & 27.8 \\
2006 & 5.4 & 12.2 & 27.7 \\
2007 & 5.3 & 12.3 & 28.3 \\
2008 & 5.7 & 13.2 & 31.4 \\
2009 Q3 & 7.8 & 18.0 & 30.3
\end{tabular}

Youth unemployment rates are particularly high for racial minorities. As we noted above, black unemployment rates ages 18-24 were 26.3\% and for Asians were $21.3 \%$. The rate for those without qualifications in the 2008 LFS was also high, at $28.9 \%$ and $47.4 \%$ for young blacks, $30.0 \%$ for young whites and $38.3 \%$ Asians respectively, without qualifications. We have special concerns regarding the employment prospects of these young people without qualifications- the disadvantaged young - going forward.

Table 9 reports the probability of a young person under 25 being unemployed using data from the 1981 and 1983-1986 pooled Labour Force Surveys again using a dprobit equation for unemployment. We chose these years as the unemployment rate was $9.6 \%$ in 1981 - the start of the bust - compared with $11.5 \%$ in $1983 ; 11.8 \%$ in $1984 ; 11.4 \%$ in 1985 and $11.3 \%$ in 1986 - the bust itself. As in the USA, the incidence fell hardest on the sixteen year olds, the least educated and minorities, and especially so for blacks. Unemployment was highest in the bust in Tyne and Wear and lowest in the South East.

Table 10 performs a similar exercise with LFS data for the boom times - 2006 Q1 to 2008 Q1 and the bust, 2008 Q2 to 2009 Q3. Results are similar. Incidence in the bust is highest among sixteen year olds, blacks and to a lesser extent Asians, and the least educated and in Tyne and Wear once again, but also in the West Midlands. There is evidence that university graduates have a higher incidence of unemployment than those with higher education and A-levels or equivalent and that gap has widened recently. This group will typically have less labour market experience than those with lower qualifications. In a regression on all age groups, graduates have a significantly lower risk of unemployment than the less well-qualified. 
Part of the explanation for the rise in youth unemployment in the UK has been the recent rise in the size of the youth cohort discussed earlier. This is illustrated below:

$\begin{array}{cccc} & \begin{array}{c}\text { Total UK population } \\ (\text { '000s) }\end{array} & \begin{array}{c}\# 16-24 \text { year olds } \\ (\text { '000s) }\end{array} & 16-24 \text { as \% total } \\ 1981 & 56,357 & 8,079 & 14.3 \% \\ 1986 & 56,684 & 8,332 & 14.7 \% \\ 1991 & 57,439 & 7,491 & 13.0 \% \\ 1996 & 58,164 & 6,495 & 11.2 \% \\ 2000 & 58,886 & 6,383 & 10.8 \% \\ 2001 & 59,113 & 6,504 & 11.0 \% \\ 2002 & 59,323 & 6,632 & 11.2 \% \\ 2003 & 59,557 & 6,785 & 11.4 \% \\ 2004 & 59,846 & 6,960 & 11.6 \% \\ 2005 & 60,238 & 7,099 & 11.8 \% \\ 2006 & 60,587 & 7,221 & 11.9 \% \\ 2007 & 60,975 & 7,368 & 12.1 \%\end{array}$

Source: Population Trends, 134, Winter 2008, Table 1.4.

From 1980 to 2000 the absolute and relative size of the youth cohort shrank. However, since 2000 the size of the youth cohort - the children of the baby boomers - has grown steadily, from 6.4 million (10.8\% of the population) in 2000 to 7.4 million $(12.1 \%)$ in 2007. The growth of the 16-24 cohort has thus been faster than the overall growth in the population. The number of 16-24 year olds in 2007 is still around seven hundred thousand less than the number in 1981 (8.1 million). However, the size of that cohort will decline quite rapidly. The following numbers are taken from Key Population and Vital Statistics, 2006 and they show the numbers of children by single year of age (in thousands) in mid 2006.

$\begin{array}{lccc}\text { Age in 2006 } & \text { Cohort size ('000s) } & \text { Age in 2006 } & \text { Cohort size ('000s) } \\ 0 & 732 & 13 & 759 \\ 1 & 716 & 14 & 785 \\ 2 & 705 & 15 & 800 \\ 3 & 681 & 16 & 791 \\ 4 & 663 & 17 & 791 \\ 5 & 664 & 18 & 809 \\ 6 & 680 & 19 & 805 \\ 7 & 700 & 20 & 810 \\ 8 & 713 & 21 & 825 \\ 9 & 732 & 22 & 808 \\ 10 & 728 & 23 & 793 \\ 11 & 732 & 24 & 788 \\ 12 & 749 & & \end{array}$


The growth of the age 16-24 cohort is a temporary phenomenon. It will start to decline in absolute and relative size from 2009 onwards as the larger older cohorts drop out and the younger smaller ones are added. For example, in 2009 there are approximately 825,000 24 year olds (age 21 in 2006) who will drop out and will be replaced by 749,000 fifteen year olds (aged 12 in 2006) so the cohort will shrink by around 75,000. Analogously, it will drop by a similar number the next year. Figure 2 illustrates the changing cohort sizes in the UK.

Of particular concern also in the UK is the high proportion of young people who are not in education employment or training (NEET). In 2009 Q3 there were 261,000 16-18 year olds and 933,000 18-24 year olds classified as NEET. ${ }^{12}$ Overall $18 \%$ of $16-24$ year olds were in this category. Low-skilled youth who become NEET find it more difficult to reengage in employment and learning than 16-24-year olds on average and there is evidence that they may become trapped in NEET. In October 2008 The Prince's Trust, conducted a survey of 2,004 16- to-25 year olds and found that 27\% of NEETs reported that life has 'no purpose', compared with $14 \%$ overall. Only $60 \%$ of NEETs said they were happy compared with $71 \%$ for all young people. ${ }^{13}$

Godfrey et al (2002) estimated the costs of being NEET for the Department for Education and Skills. ${ }^{14}$ They considered social costs as well as public finance costs over the current, medium and long-term. These included estimates of the costs of educational underachievement, unemployment, inactivity, crime and health. The authors were not able to estimates of the costs of the lowering of the skills base and hence their findings may underestimate the full costs. Their major finding was that the 157,000 NEETs aged 16-18 present in the UK population in 1999 would accrue additional lifetime costs of around $£ 7 \mathrm{bn}$ (2001 prices) in resource terms and $£ 8.1 \mathrm{bn}$ in additional public spending. The per capita equivalents are $£ 45,000$ in resource costs and $£ 52,000$ in public finance costs.

\section{Causes of Unemployment}

The orthodox explanation of unemployment that argues that institutions matter has been subject to fairly extensive econometric testing, and in recent years, the validity of the empirical results supporting this view has been called into question. ${ }^{15}$ It has proved difficult to estimate a set of cross-country panel unemployment regressions that contain a

\footnotetext{
${ }^{12}$ See http://www.dcsf.gov.uk/rsgateway/DB/STA/t000751/index.shtml

13 'The Prince's Trust YouGov Youth Index', 2008

${ }^{14}$ Godfrey, C., Hutton, S., Bradshaw, J., Coles, B., Craig, G. and Johnson, J., (2002), Estimating the Cost of Being 'Not in Education, Employment or Training' at Age 16-18, Research Report 346, Department for Education and Skills.

15 R. Layard, S.N. Nickell and R. Jackman (2005), Unemployment, macroeconomic performance and the labour market, Oxford University Press, $2^{\text {nd }}$ edition. S.N. Nickell (2006), 'A picture of European unemployment: success and failure', in Structural unemployment in Western Europe, edited by $\mathrm{M}$. Werding, CESifo Seminar Series, MIT Press, Cambridge, MA.
} 
lagged unemployment rate and a full set of year and country dummies and show that any of the labour market rigidity variables work. This is a crucial test. This is the first main similarity between European labour markets: labour market institutions do not tend to cause unemployment. The major exception is changes in the replacement rate, which, in some specifications, do appear to be negatively correlated with changes in the unemployment rate. Blanchard and Wolfers (2000) have argued that "the interaction of shocks and institutions does a good statistical job of fitting the evolution of unemployment both over time and across countries." This result is questionable because it is obtained in an over-fitted model - few data points and lots of variables - and the results appear to be driven by the cross-section variation rather than by any time series changes. ${ }^{16}$ There are only eight time series data points as they use five-year averages from 1960-1995.

As an illustration, we ran a pooled cross-country time series using the CEP/OECD Institutions data for 1975-2002 for eighteen OECD countries (Australia; Austria; Belgium; Canada; Denmark; Finland; France; Germany; Ireland; Italy; Japan; Netherlands; Norway; Portugal; Spain; Sweden; United Kingdom, and the United States). We included controls for union density, the strictness of employment protection legislation, gross benefit replacement rates data and the tax wedge. ${ }^{17}$ The dependent variable was the $\log$ of the unemployment rate and the equation includes a full set of country and year dummies. Coefficients and t-statistics are as follows. Only the lagged dependent variable is significant in any specification, whether the model is run without year dummies or country dummies (column 1); with year dummies (column 2) or both country and year dummies (column 3). The 'flexibility' explanation of unemployment is wrong.

Log of unemployment rate t-1 $_{1}$

Union density

Employment protection

Benefits

Tax wedge

Year dummies

Country dummies

$\mathrm{R}^{2}$

$\mathrm{N}$
(1)

(2)

$.9333(80.39)$
$-.0004(0.91)$
$.0376(1.62)$
$-.0002(0.24)$
$.0002(0.24)$
No
No
.9434
480

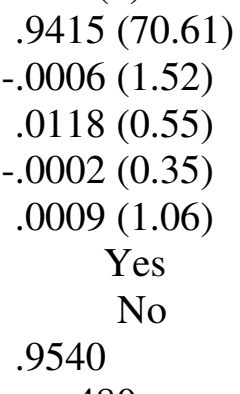

480
Yes

Yes

.9647

480

(Dependent variable $=\log$ of unemployment rate $_{t}$.

In a recent article, Howell et al (2007) econometrically examined the impact of these rigidity variables, or what they call Protective Labor Market Institutions (PLMIs), and

\footnotetext{
${ }^{16}$ Blanchard, O., and Wolfers, J. (2000), 'The role of shocks and institutions in the rise of European unemployment: the aggregate evidence', Economic Journal, 110 (462) 1-33.

17 The names in parentheses are variable names as explained in W. Nickell (2006), 'The CEP - OECD Institutions Data Set (1960-2004)', Centre for Economic Performance, LSE, September.
} 
concluded that: "while significant impacts for employment protection, benefit generosity, and union strength have been reported, the clear conclusion from our review of these studies is that the effects for the PLMIs is clearly not robust, with widely divergent coefficients and levels of significance." Indeed, in his published comments on the Howell et al. article, Jim Heckman (2007) argues that the authors "... are convincing in showing the fragility of the evidence on the role of labour market institutions in explaining the pattern of European unemployment, using standard econometric methodology."

Freeman (2007) also finds the evidence for the impact of these institutional variables less than convincing "despite considerable effort, researchers have not pinned down the effects, if any, of institutions on other aggregate economic outcomes, such as unemployment and employment". ${ }^{18}$ In a recent article, Horst Feldmann examined how the quality of industrial relations affects unemployment in developing countries and found relatively moderate effects, especially for females. ${ }^{19}$

There is no evidence in any country over the last year or so that union density, benefits, the tax wedge or employment protection has risen. Western Europe has more job protection, higher unemployment benefits, more union power, and a more generous welfare state and it has experienced a smaller rise in unemployment than the United States during the current recession. The US unemployment rate rose above that in the EU during 2009 - the first time it had done so for many years.

The increases in unemployment we have observed in the OECD over the last year or so are not due to decreases in labour market flexibility. It is not that frictions in the market have increased: rather, there has been a collapse in the demand for labour as product demand has fallen, which in turn reflects severe credit rationing, falling consumer confidence, responses to transitory shocks in raw materials prices and delayed response by monetary authorities to these developments. None of these issues directly impinge on the labour market or on the extent to which institutional arrangements affect its efficiency. It is the fall in demand for labour that is the culprit.

\section{The Impact of Unemployment - What We Know From the Literature}

1) Unemployment is a stressful life event that makes people unhappy. ${ }^{20}$ Increases in the unemployment rate lower the happiness of everyone, not just the unemployed. The fear of becoming unemployed in the future lowers a person's subjective wellbeing. ${ }^{21}$

\footnotetext{
${ }^{18}$ D. Howell, D. Baker, A. Glyn and J. Schmitt (2007), 'Are protective labour market institutions at the root of unemployment? A critical review of the evidence', Capitalism and Society, 2(1), pp. 171. Heckman, J. (2007), 'Comments on 'Are protective labour market institutions at the root of unemployment? A critical review of the evidence by David Howell, Dean Baker, Andrew Glyn and John Schmitt', Capitalism and Society, 2(1), Article 5, pp. 15. R.B. Freeman (2007), 'Labor market institutions around the world', NBER WP\#13242. D.G. Blanchflower (2001), 'Unemployment, wellbeing and wage curves in Eastern and Central Europe', Journal of the Japanese and International Economies, 15(4), pp. 364-402.

${ }^{19}$ H. Feldmann (2009), 'The quality of industrial relations and unemployment in developing countries', Review of Development Economics, 13(1), pp. 56-69.

${ }^{20}$ L. Winkelmann and R. Winkelmann (1998), 'Why are the unemployed so unhappy? Evidence from panel data', Economica, 65(257), pp. 1-15. A.E. Clark and A.J. Oswald (1994), 'Unhappiness and
} 
2) Unemployment increases susceptibility to malnutrition, illness, mental stress, and loss of self-esteem, leading to depression. ${ }^{22}$ Goldsmith, Veum and Darity $(1996,1997)$ found, for example, using data from the US national Longitudinal Study of Youth (NLSY) that being jobless injures self-esteem, and fosters feelings of externality and helplessness among youths. Moreover, they also found evidence that the psychological imprint of joblessness persists. The unemployed also appear to have a higher propensity to commit suicide ${ }^{23}$. Further, unemployment can reduce the life expectancy of workers. ${ }^{24}$ An additional negative medical indication is that unemployment increases the probability of poor physical health outcomes such as heart attacks in later life. ${ }^{25}$

unemployment', Economic Journal, 104(424), pp. 648-659. B.S. Frey and A. Stutzer (2002), Happiness and Economics, Princeton University Press. Ahn, N., J.R. García and J.F. Jimeno (2004), 'The impact of unemployment on individual well-being in the EU', European Network of Economic Policy Institutes, Working Paper No 29.

${ }^{21}$ Di Tella R., MacCulloch R.J. and A.J. Oswald (2001), 'Preferences over inflation and unemployment: evidence from surveys of happiness', American Economic Review, 91, pp. 335-341. Di Tella R., MacCulloch R.J. and A.J. Oswald (2003), 'The macroeconomics of happiness', Review of Economics and

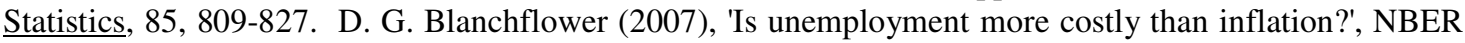
Working Paper W13505, October. D.G. Blanchflower, David (1991), 'Fear, unemployment and pay flexibility', Economic Journal, 101, pp. 483-496. A. Knabe and S. Rätzel (2008), 'Scarring or scaring? The psychological impact of past and future unemployment', Otto-von-Guericke-University Magdeburg, February 21.

${ }^{22}$ M. Linn, R. Sandifer and S. Stein (1985), 'Effects of unemployment on mental and physical health', American Journal of Public Health, 75, pp. 502-506. M. Frese and G. Mohr (1987), 'Prolonged unemployment and depression in older workers: a longitudinal study of intervening variables, Social Science and Medicine, 25, pp. 173-178. P. Jackson and P. Warr (1987), 'Mental health of unemployed men in different parts of England and Wales', British Medical Journal, 295, p. 525. M.H. Banks and P.R. Jackson (1982), 'Unemployment and the risk of minor psychiatric disorder in young people: cross-sectional and longitudinal evidence', Psychological Medicine, 12, pp. 789-798. Darity, W.R. Jr. and A.H. Goldsmith (1996), 'Social psychology, unemployment and macroeconomics', Journal of Economic Perspectives, 10(1), Winer, pp. 121-140. A.H. Goldsmith, J.R. Veum and W. Darity (1996), 'The psychological impact of unemployment and joblessness', Journal of Socio-Economics, 25(3), April, pp. 333-358. A.H. Goldsmith, J.R. Veum and W. Darity (1997), 'Unemployment, joblessness, psychological well-being and self-esteem: theory and evidence', Journal of Socio-Economics, 26(2), April, pp. 133-158. M.H. Brenner and A. Mooney (1983), Unemployment and health in the context of economic change', Social Science and Medicine, 17(16), pp. 1125-1138.

${ }^{23}$ Platt, S. (1984) 'Unemployment and suicidal behaviour: A review of the literature.' Social Science \& Medicine. Vol 19(2), pp 93-115. T A Blakely, S C D Collings, J Atkinson (2003) 'Unemployment and suicide. Evidence for a causal association?' Journal of Epidemiological Community Health; 57, pp 594600

24 Brenner and Mooney (1984) ibid, K.A. Moser, P.O. Goldblatt, A.J. Fox and D.R. Jones (1987), 'Unemployment and mortality: comparison of the 1971 and 1981 longitudinal study census samples', British Medical Journal; 1, pp.86-90. K.A. Moser, P.O. Goldblatt, A.J. Fox and D.R. Jones (1990), 'Unemployment and mortality' in: Goldblatt P., editor. Longitudinal study: mortality and social organisation. London: OPCS, 1990. (Series LS No. 6.)

25 N. Beale and S. Nethercott (1987), 'The health of industrial employees four years after compulsory redundancy', Journal of the Royal College of General Practitioners, 37 pp. 390-394. L. Iverson and S. 
3) The long-term unemployed are at a particular disadvantage trying to find work. The effects of unemployment appear to depend a lot on how long the person has been unemployed. $^{26}$ People's morale sinks as the duration of unemployment rises. Long-term unemployment is especially harmful.

4) Unemployment while young, especially of long duration, causes permanent scars rather than temporary blemishes. ${ }^{27}$ For the young a spell of unemployment does not end with that spell; it raises the probability of being unemployed in later years and has a wage penalty. These effects are much larger than for older people. Ellwood (1982) examined the persistence and long-term impacts of early labor force experiences. He reports a rise in employment rates for a cohort of young men as they age, but points out that those persons with poor employment records early have comparatively poor records later. The paper found that the effects of a period without work do not end with that spell. A teenager who spends time out of work in one year will probably spend less time working in the next than he would have had he worked the entire year. Furthermore, Ellwood concluded that the lost work experience was reflected in considerably lower wages. The reduced employment effects Ellwood examined appeared to die off very quickly. What appeared to persist were effects of lost work experience on wages.

More recently Mroz and Savage (2006) reached a similar conclusion using data from the NLSY for the US and also found evidence of long-lived blemishes from unemployment. A six month spell of unemployment at age 22 would result in an 8 per cent lower wage at 23 and even at ages 30 and 31 wages were 2-3 per cent lower than they otherwise would have been. Kletzer and Fairlie (1999) also using data for the US estimate that for young unemployed workers the costs of job loss in terms of annual earnings are $8.4 \%$ and $13.0 \%$, for boys and girls, respectively. ${ }^{28}$

Gregg and Tominey (2005) found using data from the NCDS for the UK that there was a significant wage penalty of youth unemployment even after controlling for education,

Sabroe (1988), 'Participation in a follow-up study of health among unemployed and employed people after a company closedown: drop outs and selection bias,' Journal of Epidemiology and Community Health, 42: 396-401. I. Mattiasson, F. Lindgarde, J.A. Nilsson and T. Theorell (1990), 'Threats of unemployment and cardiovascular risk factors: longitudinal study of quality of sleep and serum cholesterol concentrations in men threatened with redundancy', British Medical Journal, 301, pp. 461-466.

${ }^{26}$ Blanchard, O. (1989) 'Hysteresis in Unemployment', European Economic Review, 31, 1/2, pp. 288-295.

Røed, Knut, 'Hysteresis in Unemployment' Journal of Economic Surveys, 11, 4, December, pp. 389-418

London: Blackwell Publishing

${ }^{27}$ David Ellwood (1982), 'Teenage Unemployment: Permanent Scars or Temporary Blemishes?' in The Youth Labor Market Problem: Its Nature, Causes and Consequences, edited by Richard B. Freeman and David A. Wise, pp. 349-390. Chicago: University of Chicago Press, 1982

28 T.A. Mroz and T.H. Savage (2006), 'The long-term effects of youth unemployment', Journal of Human Resources, Spring, 41(2), pp. 259-293. R. Fairlie and L.G. Kletzer (2003), 'The long-term costs of job displacement among young workers,' Industrial and Labor Relations Review, 56(4), pp. 682-698. 
region and a wealth of family and personal characteristics. Their results suggested a scar from youth unemployment of $13-21 \%$ age 41 although this penalty was lower at $9-11 \%$ if individuals avoid repeat exposure. ${ }^{29}$ Gregg (2001) also used NCDS data to show that unemployment experience up to the age of 23 drives unemployment in subsequent years. ${ }^{30}$

Arulampalam (2001) found that joblessness leaves permanent scars on people and reduces the probability of employment and future earnings and increases the risk of future unemployment. She found that a spell of unemployment carries a wage penalty of $6 \%$ on re-entry in Britain, and after three years, they are earning 14\% less compared to what they would have received absent unemployment. Arulampalam et al (2000) also found evidence of unemployment persistence, especially for young men. Narendranathan and Elias (1993) also find evidence of state dependence and report that 'the odds of becoming unemployed are 2.3 times higher for youths who were unemployed last year than for youths who were not unemployed' (p.183). Arulampalam et al. (2001) also report that the best predictor of an individual's future risk of unemployment is his past history of unemployment. They find that unemployment has a scarring effect for both future unemployment and future earnings. In addition Burgess et al. (1999) find that unemployment while young raises the probability of subsequent unemployment, but the size of any effect varies by skill level. ${ }^{31}$ We present some new evidence of our own on this important topic in the next section.

5) As unemployment rates increase, crime rates tend to rise, especially property crime. ${ }^{32}$ Indeed, there is some recent evidence that property crime has now started to increase in

${ }^{29}$ P.A. Gregg and E. Tominey (2005), 'The wage scar from male youth unemployment', Labour Economics, 12, pp. 487-509

${ }^{30}$ P. Gregg (2001), 'The impact of youth unemployment on adult unemployment in NCDS', Economic Journal, 111(475), pp. F623-F653.

31 W. Arulampalam (2001), 'Is unemployment really scarring? Effects of unemployment experiences on wages', Economic Journal, (111), November, pp: F585-F606. W. Narendranathan and P. Elias (1993), 'Influences of past history on the incidence of youth unemployment: empirical findings for the UK', Oxford Bulletin of Economics and Statistics, 55, pp. 161-185. W. Arulampalam, A. Booth and M. Taylor (2000), 'Unemployment persistence', Oxford Economic Papers, 52, pp. 24-50. S. Burgess, C. Propper, H. Rees and A. Shearer (2003), 'The class of 1981: the effects of early career unemployment on subsequent unemployment experiences, Labour Economics, 10(3), June, pp. 291-309. For a useful summary of the school to work transition see S. Bradley and Nguyen, A.N. (2004), 'The school-to-work transition'. In: G. Johnes and J. Johnes (Eds.), International Handbook on the Economics of Education. Edward Elgar, Cheltenham, Glos.

${ }^{32}$ T. Thornberry and R. Christensen (1984), 'Unemployment and criminal involvement. An investigation of reciprocal causal structures', American Sociological Review, 56, pp. 609-627. M. Lin (2008), 'Does unemployment increase crime? Evidence from US data, 1974-2000', Journal of Human Resources, 43(2), Spring, pp. 413-436. S. Raphael and R. Winter-Ebmer (2001), 'Identifying the effect of unemployment on crime', Journal of Law and Economics, 44(1), pp. 259-283. D. Fougere, F. Kramarz and J. Pouget (2006) 'Youth unemployment and crime in France', CEPR Discussion paper \# 5600. For a discussion of the relationship between unemployment and crime see R.B. Freeman (1999), 'The economics of crime', in Handbook of Labor Economics, Volume 3C, edited by O.C. Ashenfelter and D. Card, North Holland. 
the UK. According to the British Crime Survey for the period July to September 2008, police recorded domestic burglaries rose by four per cent. ${ }^{33}$ Thornberry and Christensen (1984), for example, find evidence that a cycle develops whereby involvement in crime reduces subsequent employment prospects which then raises the likelihood of participating in crime.

Fougere et al (2006) find that increases in youth unemployment causes increases in burglaries, thefts and drug offences. Hansen and Machin (2002) find a statistically significant negative relationship between the number of offences reported by the police over a two year period for property and vehicle crime and the proportion of workers paid beneath the minimum before its introduction. ${ }^{34}$ Hence, there are more crime reductions in areas that initially, had more low-wage workers. Falk and Zweimuller (2005) find a significant positive relation between unemployment and right-wing criminal activities.

Carmichael and Ward (2001) found in Great Britain that youth unemployment and adult unemployment are both significantly and positively related to burglary, theft, fraud and forgery and total crime rates. For each of these offence categories the relationship between youth unemployment and the specific crime was found to be somewhat stronger. Carmichael and Ward (200) found that there is a systematic positive relationship between burglary rates and male unemployment regardless of age. ${ }^{35}$

6) The youth labour market is highly cyclically sensitive. There is a considerable body of evidence suggesting that the young, the least educated and especially minorities are hardest in a recession. ${ }^{36}$ Youth unemployment rates continue to be more sensitive to business-cycle conditions than the adult unemployment rate, as many studies have shown (OECD, 2008). ${ }^{37}$ Young unskilled men from minority groups are thus particularly hard hit. This is true around the world.

Clark and Summers (1982), in their classic study of the dynamics of youth joblessness

${ }^{33}$ Crime in England and Wales Quarterly Update to September 2008, Home Office Statistical Bulletin, Second Edition 01/09, Home Office, $22^{\text {nd }}$ January 2009.

${ }^{34}$ K. Hansen and S. Machin (2002), 'Spatial crime patterns and the introduction of the UK Minimum Wage', Oxford Bulletin of Economics and Statistics, 64, pp. 677-699.

35 A. Falk and J. Zweimuller (2005), 'Unemployment and right-wing extremist crime' CEPR Discussion Paper \#4997. F. Carmichael and R. Ward (2001), 'Male unemployment and crime in England and Wales', Economics Letters, 73, pp. 111-115. F. Carmichael and R. Ward (2000), 'Youth unemployment and crime in the English regions and Wales', Applied Economics, 32(5), April, pp. $559-571$.

${ }^{36}$ D.G. Blanchflower and R.B. Freeman (editors), Youth Employment and Joblessness in Advanced Countries, University of Chicago Press and NBER, 2000 and Freeman, R. B. and D. A. Wise, (editors), The Youth Labor Market Problem: Its Nature, Causes, and Consequences, University of Chicago Press and NBER, 1982

37 OECD (2008a), 'Off to a good start? Youth labour market transitions in OECD countries', $\underline{\text { OECD }}$ Employment Outlook, 2008, pp. 25-77, Paris, France. 
argue that the problem of teenage unemployment arises from a shortage of jobs. "Aggregate demand has a potent impact on the job prospects and market experience of teenagers" (1982, p.230). ${ }^{38}$ Freeman and Wise (1982), for example, found in their study of youth joblessness in the 1970s that it was concentrated, by and large, among a small group who lacked work for extended periods of time. ${ }^{39}$ Over half of the male teenage unemployment they examined was among those who were out of work for over six months, a group constituting less than $10 \%$ of the youth labor force and only $7 \%$ of the youth population. Freeman and Wise reported that the youths who make up the relatively small group that was chronically without work had distinctive characteristics, They were disproportionately black; disproportionately high school dropouts, and disproportionately residents of poverty areas.

Blanchflower and Freeman (2000) identified one basic pattern in the job market for young workers: the disproportionately large response of youth employment or unemployment to changes in overall unemployment. ${ }^{40}$ They argued that the sensitivity of youth employment and unemployment to the overall rate of unemployment dominate sizable demographic and structural changes favorable to youth in determining how youths fare in the job market. This was also confirmed in Blanchflower and Freeman (1996) and Makeham (1980). ${ }^{41}$ Recently OECD (2008a) confirmed this conclusion "Youth unemployment rates are more sensitive to business-cycle conditions than the adult unemployment rate and this high-sensitivity tends to decline progressively with age". ${ }^{42}$

There is also evidence that young people do especially well in booms. Freeman and Rodgers (1999) who analyzed the 1990s boom in the United States and found that it substantially improved the position of non-college educated young men, especially young African Americans who are the most disadvantaged and troubled group in the US. ${ }^{43}$ Young men in tight labor markets experienced a substantial boost in both employment

${ }^{38}$ K.B. Clark and L.H. Summers (1982) 'The dynamics of youth unemployment' in Freeman, R. B. and D. A. Wise, (editors), The Youth Labor Market Problem: Its Nature, Causes, and Consequences, University of Chicago Press and NBER.

${ }^{39}$ Richard B. Freeman and David A. Wise (1982), 'The youth labor market problem: its nature causes and consequences:' in Freeman, R. B. and D. A. Wise, (editors), The Youth Labor Market Problem: Its Nature, Causes, and Consequences, University of Chicago Press and NBER.

${ }^{40}$ D.G. Blanchflower and R.B. Freeman (2000).

41 D.G. Blanchflower and R.B. Freeman (1996), 'Growing into Work: Youth and the Labour Market over the 1980s and 1990s', OECD Employment Outlook, OECD, Paris and P. Makeham (1980), 'Youth unemployment. An examination of evidence on youth unemployment using national statistics', Department of Employment Research Paper No. 10, London.

${ }^{42}$ OECD (2008a), 'Off to a good start? Youth labour market transitions in OECD countries', $\underline{\text { OECD }}$ Employment Outlook, OECD, Paris.

43 Freeman, R.B. and W.M. Rodgers (1999), 'Area economic conditions and the labor market outcomes of young men in the 1990s expansion’, NBER Working Paper \#7073, Cambridge, MA. 
and earnings. Adult men had no gains and their earnings barely changed even in areas where unemployment rates were below $4 \%$. Youths did particularly well in areas that started the boom at lower jobless rates suggesting they would "benefit especially from consistent full employment" (Freeman and Rodgers, 1999, p.2). As unemployment amongst the young goes down and the attractiveness of work increases, because there are more jobs and better paying jobs out there and it becomes a virtuous cycle. Freeman and Rodgers found evidence that once that occurred in the US the crime rate dropped. Increase aggregate demand and youths, especially disadvantaged youths, seem to do best in booms.

We have investigated another aspect of cyclical sensitivity - whether the demand for younger workers' labour falls at the intensive margin as well as the extensive margin of the labour market during recessions. Those aged 16-24 typically work shorter hours than prime-age workers. But we were unable to identify any significant reduction in these hours during the current recession, conditional on their other characteristics. To establish this, we used the most recent nineteen quarters of the UK LFS. The data cover the period to Q3 2009, and therefore include 7 "recession" quarters - when unemployment was rising. We conducted regressions for both males and females distinguishing the prerecession and recession periods, younger and prime-age workers. Total weekly hours (basic and overtime) was the dependent variable. Conditional on industry sector, region and manual/non-manual status, we were unable to establish that the interaction of younger workers with the recession period was significantly different from zero. Thus, though we did show that the current recession had significant negative effects on all workers hours, we found no evidence that younger workers hours are falling faster than those of prime age workers.

\section{Unemployment and the Youth Labour Market}

In this section, we make four contributions to the literature on youth unemployment, all of which use evidence from the current recession. First, we show that youths have not priced themselves out of jobs, reinforcing the message that lack of demand is the primary cause behind the recent rise in unemployment. Second, we show that polarization of the labour market may adversely affect young peoples' progression through the labour market. Third, we present new evidence on happiness of the young. Finally, we present further evidence that unemployment while young creates permanent scars.

\section{a) Are youths pricing themselves out of jobs?}

There has been considerable interest in the possibility that youth have priced themselves out of jobs. Wells (1983) examined the relative pay and employment of young people for the period 1952-1979. During the earlier period the pay of boys to men increased from 42.0 in 1952 to 46.9 in 1969 and for girls to men it fell from 34.0 to 32.4. However, during the period 1969-1981 the boys to men ratio rose from 46.9 to 56.2 while the girls to men ratio increased from 32.5 to 40.4. Econometric analysis confirmed the finding found that the pay and employment of young people under the age of 18 for the period 1969-81 "appears to have been reduced by increases in their relative earnings relative to 
the average earnings of adults....No such effect could be found for the period 1952-1969" (p.1). ${ }^{44}$

Subsequently the relative earnings of youth have declined steadily. OECD (1986) found that from the 1970s through the early 1980s the earnings of youth fell relative to the earnings of adults in several countries. ${ }^{45}$ The finding that youths were overpriced relative to adults has not been replicated in subsequent periods, as youth relative wages have fallen steadily. Blanchflower and Freeman (2000) examined the relative earnings of youths aged 16-19 and 20-24 to those of adults in 11 OECD countries (Australia; Canada; Denmark; France; Germany; Italy; Japan; Norway; Sweden; the United Kingdom and the United States) and found that there were declines in the relative earnings of the young throughout the 1990s in each of these countries except Sweden, despite the fact that the size of the youth cohort was shrinking. O'Higgins (1997) also concluded that there was no close relationship between the relative wages of youth and their unemployment rates. "Indeed, the impression is that, more often than not, unemployment and relative wage rates appear to be moving in opposite directions to each other". ${ }^{46}$

The finding that the relative pay of the young has continued to decline over the last decade or so is confirmed below for the UK using data from Annual Survey of Hours and Earnings (ASHE) - previously the New Earnings Survey (NES). Gross hourly earnings of 18-21 year olds are compared to overall earnings and adults age 40-49 for the period 1997-2008. It is clear that the relative earnings of the young have fallen steadily since 1997 when the youth share of total unemployment started to rise.

$\begin{array}{ccc} & 18-21 / \text { total } & 18-21 / 40-49 \text { years } \\ 2008 & 51.8 \% & 45.8 \% \\ 2007 & 52.5 \% & 46.6 \% \\ 2006 & 51.3 \% & 45.3 \% \\ 2005 & 51.1 \% & 45.0 \% \\ 2004 & 52.0 \% & 46.2 \% \\ 2003 & 52.6 \% & 46.2 \% \\ 2002 & 52.8 \% & 47.6 \% \\ 2001 & 53.7 \% & 48.4 \% \\ 2000 & 53.7 \% & 47.8 \% \\ 1999 & 55.6 \% & 49.6 \% \\ 1998 & 54.6 \% & 48.5 \% \\ 1997 & 54.9 \% & 48.6 \%\end{array}$

Source: ASHE.

http://www.statistics.gov.uk/StatBase/Product.asp?vlnk=13101\&Pos=1\&ColRank=1\&Rank=208

${ }^{44}$ W. Wells (1983), 'The relative pay and employment of young people', Department of Employment Occasional Paper \# 42.

${ }^{45}$ OECD (1986), OECD Employment Outlook, OECD, Paris, France.

${ }^{46}$ N. O'Higgins (1997), 'The challenge of youth unemployment', Employment and labour market policies branch action programme on youth unemployment ', ILO, Geneva. 
OECD (2008a) presented evidence on youth (20-24) earnings relative to adult earnings across countries. The evidence is presented below and suggests that a) this ratio in the UK has fallen over time and b) now is below the OECD average but was above it in 1996.

$\begin{array}{lcc} & 2006 & 1996 \\ \text { Australia } & .73 & .74 \\ \text { Canada } & .64 & .62 \\ \text { Denmark } & .65 & .72 \\ \text { Finland } & .68 & .70 \\ \text { Germany } & .61 & .62 \\ \text { Ireland } & .67 & .61 \\ \text { Japan } & .60 & .62 \\ \text { New Zealand } & .75 & .75 \\ \text { Sweden } & .68 & .73 \\ \text { UK } & .60 & .68 \\ \text { USA } & .57 & .58 \\ \text { OECD } & .64 & .67\end{array}$

The evidence that suggests that the high relative wages of the young is responsible for pricing them out of the jobs comes only from the 1970s. This is the period of most rapid increase in union activity. Union membership peaked in the 1970 s with union density the proportion of workers who are members of trade unions - at a little over $50 \%$ (Lindsay, 2003). Since that time union membership numbers and density rates have fallen. In 2007 union density had fallen to $25 \%$ and $15.9 \%$ among private sector British employees. Unions generally operate rates for the job, which would have the effect of raising the relative wage of the young, and hence making them relatively less attractive, and then lowering their employment. Union membership rates among the young in the UK are especially low. Blanchflower (2007) shows, using data from the LFS that union density rates for 16-19 year olds in 2004 were 4.3\%. In 2007 the union density rates for 16-24 year olds was 9.8\% (Mercer and Notley, 2008, Table 25). ${ }^{47}$ It does not appear that youths are pricing themselves out of work currently, unless their relative productivity is falling especially sharply, but we have no evidence to suggest that this is the case. But this may change as unemployment rises.

A further possibility is that the National Minimum Wage, which was introduced in the UK in 1997, might have reduced employment of the young. There is little or no evidence

\footnotetext{
${ }^{47}$ C. Lindsay (2003), 'A century of labour market change: 1900-2000', Labour Market Trends, March, pp. 133-144. S. Mercer and R. Notley (2008), Trade Union Membership, 2007, July., Department of Business, Enterprise and Regulatory Reform, http://stats.berr.gov.uk/UKSA/tu/tum2008.pdf. D.G. Blanchflower (2007), 'International patterns of union membership', British Journal of Industrial Relations, March, 45(1), pp. 1-28.
} 
to sustain that claim either. ${ }^{48}$ There is some evidence to suggest that the influx of workers, who were generally working in less skilled jobs, from the ten Accession countries did have some negative impact in the period since 2004 on the employment of the least skilled young people. ${ }^{49}$ But these effects are usually insignificant or when significant, quite small.

\section{b) How is industrial change impacting young people's labour market prospects?}

The changing structure of labour demand may also be adversely affect young people's labour market prospects. Autor, Levy and Murnane argue that industrial change in the USA has led to a significant change in the demand for skills. ${ }^{50}$ Rather than additions to labour demand being entirely focused on high-skilled jobs, there has been some increase in demand for low-skilled workers. Many such jobs involve non-routine or interactive tasks that cannot be easily automated. In contrast, the demand for skilled workers has fallen, mainly as a result of automation. Such workers might typically have expected to earn wages close to the central deciles of the earnings distribution. Goos and Manning (2003) produce evidence supporting this hypothesis for the UK ${ }^{51}$ They use information from the LFS for the period 1979-1999 and define "lousy" jobs as those occupation/industry combinations where median earnings are relatively low and "lovely" jobs as those where median earnings are relatively high. They argue that both these types of jobs typically involve tasks that are not routine and therefore cannot be easily substituted by technology. Examples of "lousy" jobs might be care workers or gardeners, while lawyers or cell biologists could be said to work in "lovely" jobs. They then show that such non-routine jobs have exhibited the most rapid employment growth from 19791999, with the most rapidly growing occupations being care workers, software engineers and management consultants.

\footnotetext{
48 Metcalf, D. (2008), 'Why has the British National Minimum Wage had little or no impact on employment?', Journal of Industrial Relations, 50 (3), June. R. Dickens and M. Draca (2005), 'The employment effects of the October 2003 increase in the National Minimum Wage', CEP, February. Dickens, R., and Manning, A. (2003) 'Minimum Wage - Minimum Impact', in Dickens, R., Gregg, P. and Wadsworth, J. (eds.), The State of Working Britain, Palgrave McMillan, Basingstoke, pp 17-31 Report prepared for Low Pay Commission. M. Stewart (2002a) 'Estimating the impact of the minimum wage using geographical wage variation', Oxford Bulletin of Economics and Statistics, 64, pp. 583-605. M. Stewart (2002a) 'The employment effects of the National Minimum Wage', Economic Journal, 114, March, pp. C110)-C116. M. Stewart (2004), 'The impact of the introduction of the UK minimum wage on the employment probabilities of low wage workers', Journal of the European Economic Association, 2, pp. 67-97.

49 Blanchflower, D.G. and C. Shadforth (2009) ibid. S. Nickell and J. Saleheen (2008), 'The impact of immigration on occupational wages: evidence from Britain', Federal Reserve Bank of Boston, Working Paper \# 08-6.

50 Autor, D. H, Levy, F. and R.J. Murnane (2003), 'The skill content of recent technological change: an empirical exploration,' Quarterly Journal of Economics, CXVIII, 1279-1333

${ }^{51}$ Goos, M. and Manning, A. (2007), 'Lousy and lovely jobs: the rising polarization of work in Britain', Review of Economics and Statistics, February, 89, pp. 118-133.
} 
To see if this process continued when the UK labour market was experiencing significant growth, we repeat the Goos and Manning exercise for the period 2002 to 2008, again using LFS data. The occupational classification used in the LFS is consistent over this period. We subdivided the 2464 occupation/industry cells for which we had earnings data into deciles based on the 2002 earnings distribution. We also calculated employment in 2002 and 2008 in each cell and aggregated for each earnings decile. Finally, we calculated employment growth rates by decile using the 2002 and 2008 employment levels. We also calculated the proportion of 16-24 year olds employed in the same occupation/industry cells and aggregated across the income deciles to show how far this age group is concentrated in "lovely" or "lousy" jobs.

Most of the growth in employment between 2002 and 2008 was concentrated in jobs that would be classified as "good", because of the relatively high wages that they pay. Positive employment growth was recorded from the $7^{\text {th }}$ to the $10^{\text {th }}$ decile (see Figure 3 ). Consistent with the Autor, Levy and Murnane argument, there was a significant decline in employment in those jobs around the centre of the earnings distribution. At the bottom end the picture is more mixed. A small decline in the first decile is more than offset by a large rise in employment among those in the second decile of occupation/industry combinations. The net effect is a modest increase in employment for those whose skills place them at the lower end of the earnings distribution. Thus, although, we cannot demonstrate a causal link between the declining occupations where technical change has reduced employment opportunities, our evidence is consistent with both Autor and Manning.

Figure 3 also shows that younger people (those aged 16-24) are predominantly associated with jobs at the lower end of this distribution. Over 20 per cent of those employed in jobs located in the lowest earnings decile are aged 16-24, while only 2.2 per cent are employed in the top ten percent of occupations. Together, these results illustrate a key difficulty for the current youth labour market. Most young people enter the labour market in low-paying occupation/industry combinations, in which there has been a modest growth in employment. They may aspire to enhance their earnings by moving into better paying jobs. However, the route from lower-quality to better-quality jobs is becoming more difficult in the in the sense that employment is falling among those jobs paying around the median wage. Hence the probability of transition to better quality jobs is reduced. Thus, the young face an increasingly polarised labour market. This finding may well have implications for the design of labour market interventions designed to help the young.

\section{c) Happiness and the young}

There is a growing body of research that finds that young people are especially happy. Indeed, it appears that there is a U-shape in age in happiness equations across countries. ${ }^{52}$ There is also evidence to suggest that, in contrast to adults, the happiness of the young

52 D.G. Blanchflower and A.J. Oswald (2008), 'Is Well-Being U-Shaped over the Life Cycle?', Social Science \& Medicine, 2008, 66(6), pp. 1733-1749 and D.G. Blanchflower and A.J. Oswald (2009), 'The UShape Without Controls: A response to Glenn', Social Science and Medicine, . 
has trended up over time. Recently, though, the happiness of the young appears to have fallen. In the US General Social Survey the distribution of responses to the question how happy are you, suggests that there was a drop in the happiness of the young in 2008.

$\begin{array}{lccc} & \text { \% very happy } & \text { \% quite happy } & \text { \% not too happy } \\ 1996 & 27 & 62 & 11 \\ 1998 & 26 & 59 & 15 \\ 2000 & 28 & 63 & 9 \\ 2002 & 29 & 56 & 15 \\ 2004 & 32 & 55 & 13 \\ 2006 & 27 & 60 & 13 \\ 2008 & 24 & 58 & 18 \\ \text { Average } & 28 & 59 & 12\end{array}$

Similarly, in the Eurobarometer there has also been a drop in the happiness of the young. We compared the average weighted life satisfaction scores based on a scale of 1-4 from Eurobarometer \#71.1 for January-February 2009 and compared it with the results from the same question asked in Eurobarometer \#68.1 taken between September and October 2007, at the height of the boom. Results are shown below.

$\begin{array}{llll} & \mathbf{2 0 0 7} & \mathbf{2 0 0 9} & \text { Change } \\ \text { Austria } & 3.07 & 3.20 & -0.13 \\ \text { Belgium } & 3.25 & 3.35 & -0.10 \\ \text { Bulgaria } & 2.62 & 2.66 & -0.04 \\ \text { Cyprus } & 3.36 & 3.49 & -0.13 \\ \text { Czech Republic } & 3.05 & 3.13 & -0.08 \\ \text { Denmark } & 3.60 & 3.68 & -0.08 \\ \text { East Germany } & 2.84 & 2.81 & +0.03 \\ \text { Estonia } & 2.91 & 3.05 & -0.14 \\ \text { Finland } & 3.30 & 3.32 & -0.01 \\ \text { France } & 3.10 & 3.27 & -0.17 \\ \text { Great Britain } & 3.33 & 3.32 & 0.00 \\ \text { Greece } & 2.64 & 2.89 & -0.25 \\ \text { Hungary } & 2.62 & 2.64 & -0.01 \\ \text { Ireland } & 3.09 & 3.27 & -0.17 \\ \text { Italy } & 2.78 & 2.86 & -0.08 \\ \text { Latvia } & 2.64 & 2.99 & -0.35 \\ \text { Lithuania } & 2.78 & 3.00 & -0.22 \\ \text { Luxembourg } & 3.42 & 3.42 & 0.00 \\ \text { Malta } & 3.19 & 2.98 & +0.21 \\ \text { Netherlands } & 3.56 & 3.61 & -0.04 \\ \text { Poland } & 2.94 & 3.15 & -0.21 \\ \text { Portugal } & 2.60 & 2.87 & -0.28 \\ \text { Romania } & 2.81 & 2.65 & +0.16 \\ \text { Slovakia } & 2.95 & 2.92 & +0.03 \\ \text { Slovenia } & 3.20 & 3.50 & -0.30\end{array}$




$\begin{array}{llll}\text { Spain } & 3.22 & 3.27 & -0.05 \\ \text { Sweden } & 3.46 & 3.34 & +0.12 \\ \text { Turkey } & 2.76 & 3.01 & -0.25 \\ \text { West Germany } & 3.08 & 3.14 & -0.07\end{array}$

The happiness scores of the young fell in twenty-two out of twenty nine countries as unemployment increased. But increases were found in Romania (+.16) and Sweden $(+.12)$.

Table 12 allows us to examine how unemployment impacts the happiness of the young in Europe using data for 2009 from Eurobarometer \#71.1 for 2009 used above. Column 1 estimates an ordered logit where the dependent variable is how satisfied the individual is with the life they lead, in four categories. A positive coefficient implies happier. It is apparent, consistent with the literature (Blanchflower and Oswald, 2004, Blanchflower, 2009) that happiness is U-shaped in age - in this case lowest for the age group 45-54 and highest for the young. Happiness is lower among men, the least educated, separated and people who had previously been living together but were single at time of interview and right-wingers. The Danes, Swedes and Dutch were especially happy and young people from Eastern Europe and Greece were particularly unhappy.

Unemployment lowers people's happiness. The effect is less for the young than older individuals. This is shown by the positive and significant interaction term between unemployment and ages 15-24 dummy in the first column. The second column is restricted to youngsters only and the unemployment result remains. Unemployment makes young people unhappy but less so than for adults. These results arte confirmed in the final two columns that estimate ordered logits relating to an individual's 'job'.

Table 13 performs a similar exercise, estimating a series of life satisfaction equations for the United States using data for 2008 from the Behavioral Risk Factor Surveillance survey (BRFSS). For earlier work with these data see Oswald and Wuh (2009) and Blanchflower (2009). ${ }^{53}$ RHS controls are as in Table 12 for Europe, along with controls for states plus Guam, US Virgin Islands and Puerto Rico; although here the sample does not include youngsters under the age of eighteen. In total there are nearly 400,000 observations and just over 13000 for those age 18-24. Happiness is U-shaped in age, lower for separated people and the least educated and men are less happy in the overall sample. When the sample is restricted to the young in column 2 the sign reverses and young men are happier than young women. In both columns, unemployment lowers happiness, but just as we found for Europe this effect is smaller for the young than for adults. This is also true in columns three and four, which include controls for income. Young students are especially happy.

So increasing levels of youth unemployment will likely lower the levels of happiness of the young, but perhaps by less than older groups, perhaps because they have fewer

\footnotetext{
${ }^{53}$ D.G. Blanchflower (2009), 'Happiness and health insurance' IZA DP \#4450 and A.J. Oswald and S. Wu (2009), 'Well-being across America: evidence from a random sample of one million U.S. citizens', unpublished paper, Warwick University and Hamilton College.
} 
responsibilities. Since this is not a longitudinal study, we cannot comment on the duration of unhappiness associated with unemployment spells. Such effects may be relevant for our next contribution - the long-term effects of youth unemployment.

\section{d) Youth unemployment creates permanent scars rather than temporary blemishes}

We now turn to examine recent evidence on youth unemployment in the UK. We find evidence that spells of youth unemployment have harmful impacts on a number of outcomes - happiness, job satisfaction, wages and health - many years later.

In order to explore the impact of unemployment while young on subsequent outcomes we examined data from the 1958 birth cohort, the National Child Development Study (NCDS). The NCDS has followed a cohort of people who were born in one week - the $3^{\text {rd }}$ to the $9^{\text {th }}$ March 1958. The National Child Development Study (NCDS) is a continuing longitudinal study that seeks to follow the lives of all those living in Great Britain who were born in one particular week in 1958.

To date there have been seven attempts to trace all members of the birth cohort in order to monitor their physical, educational and social development. The first three sweeps were carried out by the National Children's Bureau, in 1965, when respondents were aged 7, in 1969 (NCDS1), aged 11 (NCDS2), in 1974, aged 16 (NCDS3). The fourth sweep, NCDS4, was conducted in 1981, when respondents were aged 23. The fifth sweep was carried out in 1991, when respondents were aged 33 (NCDS5). For the sixth wave, conducted in 1999-2000, when respondents were aged 41-42 (NCDS6), fieldwork was combined with the 1999-2000 wave of the 1970 Birth Cohort Study (BCS70). The seventh sweep of NCDS was conducted in 2004-2005, when respondents were aged 4647 years (NCDS7). It was conducted by telephone, and aimed to update the information gathered at NCDS6 in 1999-2000.

We have information available to us at age 23 in 1981 on 12537 respondents whether a) the respondent had ever been unemployed since the age of 16. Unemployment rates in the UK had risen from $5.4 \%$ in 1979 to $6.8 \%$ in 1980 and $9.6 \%$ in 1981 , when the UK had moved into recession. Unemployment would eventually peak at $11.4 \%$ in the spring of 1984. In the sample, $44 \%$ reported that at some time in their working lives they had been unemployed. The question is whether unemployment when young impacts outcomes later in life and whether the effect an unemployment spell when young is greater than when older.

Here we examine four outcomes in 2004/5 when the respondents were aged 46-47 years a) life satisfaction b) self-reported health status and two for workers only c) job satisfaction and d) (log of) gross weekly wages in 2004/5 in NCDS7. We also make use of data on whether the respondent was unemployed at age 33 in NCDS5 in 1991. The issue is whether a period of unemployment when young has lasting effects; it turns out that it does. We also include a unique set of controls identifying father's social class when the respondent was born (and reported in the PMS 1958) as well as '11-plus', verbal and non-verbal test scores reported at age 11 in NCDS2 in 1969 - tests at the local level called 11-plus were given a that time to determine entry to grammar school. We are 
also able to include an indicator variable on health at age 23 measured by the malaise score (indicating a tendency towards depression), which is highly significant. ${ }^{54}$ In addition we can include controls for marital status (5), highest qualification (7), region (8) labour force status (11) home ownership (5), registered disability and gender. In the job satisfaction equations we only include three labour force status dummies, exclude the marital status and home ownership dummies and include 58 industry dummies. In the wage equation the sample is limited to employees and hence only has a part-time employee dummy. The results show that youth unemployment continues to hurt two decades later for the four 2004/5 outcome variables listed above, while unemployment in one's early thirties has little effect. As we will see, there are permanent scars from youth unemployment.

Results are reported in Table 13. We look at the four outcomes in turn.

i) Life satisfaction. Respondents in NCDS7 were asked "On a scale from 0 to 10, where ' 0 ' means that you are completely dissatisfied and '10' means that you are completely satisfied, what number corresponds with how satisfied or dissatisfied you are with the way life has turned out so far?" The mean life satisfaction score was 7.57 and 7.71 if the respondent had not been unemployed at age 23 or before and 7.42 if they had. Column 1 reports the results of estimating an ordered logit. Most of the results are standard; life satisfaction is higher for married people, the educated, workers, especially those who work full-time, those from higher social classes home owners and those who are not disabled or sick or depressed (a low malaise score). Those currently unemployed are less happy; there are enduring effects from spells of unemployment while young, which continues to lower happiness more than two decades later. Clark et al (2001) also found, using panel data for Germany from the GSOEP that past unemployment lowers life satisfaction. ${ }^{55}$

In column 1 it is apparent that, as is consistently found in all happiness equations, the current unemployed are less happy. Also, if the individual had experienced any spell of unemployment before the age of twenty-three, this lowers happiness over twenty years later at age 46. In contrast, a spell of unemployment at age 33 has no effect on current happiness. In column 2 it is notable from the significance of the interaction term between having had a spell of unemployment up to and including age 23 and present unemployment in column 2, that the impact of past unemployment on wellbeing is greatest for those currently unemployed. This contrasts with the findings of Clark et al who found that "the negative well being effect of current unemployment is weaker for those who have been unemployed more often in the past" (2001, p. 221). The main

\footnotetext{
${ }^{54}$ For a study using the NCDS Malaise scores at ages 23 and 33 see S.Y. Cheung and A. Buchanan (1997), 'Malaise scores in adulthood of children and young people who have been in care', Journal of Child Psychology and Psychiatry, 38(5), pp. 575 - 580. For an analysis of unemployment before the age of 23 and work histories of the NCDS birth cohort see P.E. Elias and D.G. Blanchflower (1989), Occupational earnings and work histories: who gets the good jobs?, Department of Employment Research Paper No. 68.

55 A. Clark, Y. Georgellis, Y, and P. Sanfey P (2001), 'Scarring: the psychological impact of past unemployment', Economica, 68(270), pp. 221-241.
} 
difference though is that their measure of past unemployment relates to the proportion of the preceding three years that had been spent in unemployment, whereas in Table 9 it refers it an unemployment spell over twenty years earlier.

ii) Health status. Respondents in NCDS7 were asked "Please think back over the last 12 months about how your health has been. Compared to people of your own age, would you say that your health has on the whole been' - 1=excellent; 2=good; 3=fair; 4=poor or $5=$ very poor?" Of those who had been unemployed in NCDS4 $27.8 \%$ said they were in excellent health compared with $34.3 \%$ of those who had not been unemployed. Column 3 of Table 13 estimates an ordered logit with self-reported health as the dependent variable. Once again the youth unemployment variable enters significantly and negative, whereas being unemployed at age 33 did not have a significant impact on health. The Malaise score is strongly negative also. Social status of father at birth matters for health nearly fifty years later. The currently unemployed are not less healthy than full-time employees.

iii) Job satisfaction. Workers were asked for their degree of satisfaction with their current job. Possible answers were "very dissatisfied; somewhat dissatisfied; neither; somewhat satisfied and very satisfied". Column 3 reports the results of estimating an ordered logit. Youth unemployment lowered job satisfaction whereas middle-age unemployment did not.

iv) Log of gross weekly wages. Column 5 of the table estimates a log wage equation. Past unemployment is also significantly negative. Those with more education earn more, as would be expected. High IQ score at 11 continues to raise wages two decades later.

People are impacted adversely, in terms of reduced wellbeing, by increases in unemployment. The unemployed themselves lose their jobs but there is a much wider loss of wellbeing. High national unemployment lowers wellbeing especially of the unemployed. It turns out that spells of unemployment are especially harmful to the individual - and to society - when young people become unemployed. A spell of unemployment when young continues to have a negative impact in later life.

Youth unemployment is especially harmful. As we noted above there is scant evidence to suggest that increases in unemployment are attributable to the introduction of the minimum wage or to the presence of temporary workers from Eastern Europe or that the young have priced themselves out of work. The onset of recession, at a time when the size of the youth cohort has temporarily increased, has made matters considerably worse as youths are especially vulnerable to movements in the business cycle. Now is the time to act. But what should we do? This is what we turn to consider now. 


\section{Policy Measures}

Young workers are especially vulnerable to a rise in unemployment. So what kinds of policies might be worth considering in order to reduce these costs? It seems to us that there are a number of measures that can be taken to deal with the crisis. ${ }^{56}$

\section{i) Maintain or even increase aggregate demand}

The main issue in the current recession is the lack of demand. Unemployment has not risen because people have chosen to be unemployed. Unemployment is largely involuntary. The reserve army of the unemployed is a conscript army and not a volunteer army. Unemployment makes people unhappy. It lowers the happiness of the people who are unemployed but it also lowers the happiness of everyone else. Rising unemployment lowers well-being more than rising inflation. ${ }^{57}$ Withdrawing fiscal and monetary stimulus too early is likely to kill off any budding shoots.

The difficulty is that there are simply insufficient jobs available. This means that measures such as retraining, mobility grants and counseling are unlikely to be successful on their own. At the very least they will not be as successful as they were when unemployment was low. Expansion of self-employment may well get unemployment down but doesn't deal with the problem that there is little work out there so earnings may well be very low.

The loss of output associated with this slump may be permanent in some developed countries, in which case the price of labour may have to fall in the longer-run in order to return to full employment. For those countries with a substantial fiscal deficit, downward pressure on wages is likely to be strongest in the public sector. But these are longer term objectives of policy which should only be addressed once recovery is secure.

\section{ii) Target assistance on the young}

What specific labour market interventions might be targeted on younger workers?

\section{a) Active Labour Market Programs}

There is a substantial body of literature that analyses the effectiveness of labour market policies for the young. This work is summarized in Bell and Blanchflower (2008). In Europe there seems to be little evidence that active labor market policies have had a positive impact on participants' wages. There is stronger evidence that they have had positive employment effects but there is no consensus on the question. Even if there were, it is unclear the extent to which any of the newly created jobs constitute net job creation or are offset by the displacement of non-participants. In 1996 when asked how much training schemes in the US help their clientele Nobel Laureate Jim Heckman replied that 'zero is not a bad number' (Economist, 6 April, 1996).

\footnotetext{
${ }^{56}$ For an earlier examination of these issues see D.G. Blanchflower (1999), "What can be done to reduce the high levels of youth joblessness in the world?", report to the International Labor Organisation, downloadable at http://www.dartmouth.edu/ blnchflr/Projects.html

${ }^{57}$ Blanchflower (2007, 2009).
} 
In our view there is little evidence to support large scale, active labour market programs to help the young or any other group. In a recession when unemployment rates are high job placement rates from any ALMP are likely to plummet and the schemes are unlikely to provide adequate rates of return.

\section{b) Expansion of education.}

A traditional response of young people in recessions is to withdraw from the labour force. Applications to colleges and universities rise. This is a sensible response and to be encouraged. Temporary expansion of the number of places in higher and tertiary education makes sense. Possibilities exist to also encourage young people to remain in high school, perhaps with financial inducements. Given the declining size of the youth cohort any expansion in the numbers is likely to be temporary as the cohort size declines and the recession recedes.

\section{c) Wage/employment subsidies for the young}

Given the evidence that a spell of unemployment while young has especially harmful effects there is an argument to provide subsidies to private sector firms to hire them. This could take the form of a subsidy for every additional new worker hired. The concern would be that older workers would be fired but the subsidy should be based on additional net hires.

d) Incentives for hiring the young in public sector organisations such as in education and health

One possibility would be to allow public sector organisations to hire young people for say, two years, and pay them the equivalent of the benefits they would have received on unemployment benefits. This would be subsidized training.

e) Lowering the minimum wage for the young.

Where the minimum wage is high there is an argument to have it lowered. The issue is whether there is evidence that it is a binding constraint. One possibility would be to temporarily remove it for anyone under age 25 , for two years.

\section{iii) Support initiatives from the private sector}

In the UK the Confederation of British Industry (CBI) which is the main employer's association, has come up with a five-point plan to help reduce youth unemployment. Much of their programme is consonant with our findings regarding youth unemployment. Their proposals would seem to be relevant for many countries that are seeking to return to growth. In our view, their approach is worthy of support.

\section{Help employers to offer more apprenticeships}

a subsidy for firms that offer additional apprenticeships to young people, or employ an apprentice for the first time. This money would not subsidize existing apprenticeship places 
- a fund for employers who train more apprentices than they need for the benefit of their sector.

2. Ensure that employing young people is attractive

- the employment prospects for young people with low skills are very sensitive to wage levels. Youth minimum wages and apprentice rates need to be set with this in mind.

3. Practical help for young people to get a job

- more universities should offer additional practical sessions (sometimes called "boot camps") to help students get a job or start a business. Those that do this have a big impact

- companies and careers services should encourage unemployed graduates to apply for internships, volunteer, continue their studies or use their gap year constructively to help develop employability skills

- tailored support should be given to the most disadvantaged including interview technique and confidence-building sessions.

4. Offer more young people work experience

- firms should offer internships and encourage schemes for staff to mentor young people

- public and private-sector employers should open up work experience schemes to young people who are not in education, employment or training (NEET).

5. Ensure the education system teaches basic skills

- in today's labour market young people must have basic literacy and numeracy skills. The UK's performance here is still too patchy

- schools and colleges should emphasize the need to develop 'employability skills' such as communication skills and self-management.

It seems likely that public/private partnerships are especially likely to be successful in reducing youth joblessness.

\section{Conclusion}

The recession has hit right across the world, with consequent adverse effects on the demand for labor. The effects on output have varied across countries, depending on asset bubbles, imbalances in private or government debt and trade imbalances. 
Governments have generally reacted by stimulating demand through fiscal measures, thus partly offsetting the fall in private sector demand caused by credit restrictions and the loss of consumer and business confidence. Central banks around the world, including the Federal Reserve, the Bank of England, the ECB and the Sveriges Riksbank, have cut interest rates close to zero and engaged in quantitative easing for the first time since the 1930s to get their various economies moving again in the face of a threat of deflation.

Some countries have intervened more decisively than others in the labor market. Measures to subsidizes those in work have reduced redundancy levels are maintained demand particularly in countries where the replacement ratio is low. The ILO has estimated that without discretionary fiscal measures and the effects of automatic stabilizers, unemployment would have been between 7 and 11 million higher in the G20 countries during 2009.

Thus far, at a country level, increases in unemployment have not been closely related to falls in output. In some countries, the increase in unemployment has far exceeded the reduction in output, while in others the reverse is true. This may reflect increases in labor supply, large-scale redundancies among low skilled workers and/or barriers to adjustment of labor inputs that fall short of redundancy.

The countries that experienced the largest increases in unemployment tended to experience asset bubbles that peaked in 2006 or 2007. Unemployment has risen rapidly in Spain, USA, Ireland and the Baltic States. Countries that were over-reliant on exports (e.g. Germany and Japan) have experienced large falls in output, but increases in unemployment have been moderate, perhaps because of policy interventions or because management has decided to hoard labor.

Historic evidence suggests that financial crises have a long-term negative effect on economic growth. With a severe crisis, the fall could amount to a permanent reduction of output of as much as $4 \%$. This will inevitably impact the demand for labor. In these circumstances, engineering a return to full employment will be a huge challenge for the policy community. It is not clear that the supply-side policies that were popular in the 1990s and early part of this decade will form part of the solution. Perhaps further extension of the job saving measures that have been implemented may be necessary to maintain demand, albeit at the cost of higher government debt. Moves to cut public expenditure as suggested by some political groups, deep in a recession are a mistake. The danger is that they will turn a recession into a depression. As Keynes' biographer Lord Robert Skidelsky has noted recently there is no reason why this should become a depression. ${ }^{58}$

"How long will the slump last? This is the worst global turndown since the Great Depression. But it is highly unlikely to be as bad. The years 1929-32 saw twelve successive quarters of economic contraction. If repeated, this would mean the economic slide will continue till mid 2011. But the present contraction will be neither as deep nor as long and this for two reasons.

\footnotetext{
${ }^{58}$ Robert Skidelsky (2009), Keynes. The return of the master. Public Affairs, New York.
} 
First, the will to international cooperation is stronger. Second, we do have Keynes. To be a Keynesian in the 'foxhole' is not enough. But it is better than to be a classical economist in the foxhole, which was the only intellectual support that perplexed policymakers had available during the Great Depression. Governments at that time made heroic efforts to balance their budgets: they allowed banks to fail and households to default on their mortgages; they stuck to the gold standard which kept interest rates high for the first two years of the slump. Today the intellectual climate is different. The 'stimuli', which have been put in place, will stop the slide into another Great Depression. The financial system will be cleaned up, and money will become very cheap, but the collapse of confidence will continue to depress new investment for years ahead." (Skidelsky 2009, p.15)

and later.

"Keynes's big idea was to use macroeconomic policy to maintain full employment. His specific suggestion was to use monetary policy to secure a permanently low interest rate and fiscal policy to achieve a continuously high level of public or semi-public investment. Over time, as the returns on further additions to capital fell, the high-investment policy should yield to the encouragement of consumption through redistributing income from the higher to the lower-saving section of the population. This should be coupled with a reduction in the hours of work. In short, the object of macro-policy should be to keep the economy in 'quasi-boom' till the economic problem was solved and people could live 'wisely, and agreeably, and well'. (Skidelsky 2009, p.179).

We are not at the point yet of quasi-boom. We are still experiencing the dragging conditions of semi-slump.

Policy makers around the world appear to have understood this need for stimulus. What has been absent from the policy response thus far, though, is a coherent approach to the treatment of younger people who have not yet entered the labor market. We know that these are particularly vulnerable individuals, whose long-term opportunities can be damaged by adverse events early in their labor market experience. We also understand that the discounted social and health costs associated with youth unemployment are extremely high. It is thus extremely important to introduce policies which enhance the skills and capabilities of younger workers and which assist them to join the labor market as quickly as possible.

Spells of unemployment while young create permanent scars. Unemployment is higher in the years ahead if a young person doesn't make a successful toe-hold into the labour market early in their lives. Solving youth unemployment is the most pressing problem governments are facing today. Not dealing with the problem of high, and rising levels of youth unemployment hurts the youngsters themselves and has potentially severe 
consequences for us all for many years to come. The time to act is now. The young must be the priority. 
Table 1. Unemployment increases since the turning point of the recession

\begin{tabular}{|c|c|c|c|c|c|}
\hline & $\begin{array}{c}\text { Minimum } \\
\text { Unempt. } \\
\text { Rate }\end{array}$ & $\begin{array}{l}\text { Turning } \\
\text { Point }\end{array}$ & $\begin{array}{c}\text { Latest } \\
\text { Unempt. } \\
\text { Rate }\end{array}$ & $\begin{array}{c}\text { Latest } \\
\text { observation }\end{array}$ & $\begin{array}{c}\text { Growth in } \\
\text { Unempt. } \\
\text { Rate }\end{array}$ \\
\hline Spain & 7.9 & May-2007 & 19.3 & Sep-2009 & 11.4 \\
\hline Ireland & 4.3 & Jan-2007 & 13.0 & Sep-2009 & 8.7 \\
\hline United States & 4.4 & Mar-2007 & 10.2 & Oct-2009 & 5.8 \\
\hline Turkey & 8.1 & Dec-2006 & 13.2 & Jun-2009 & 5.1 \\
\hline Denmark & 3.1 & Jun-2008 & 6.4 & Sep-2009 & 3.3 \\
\hline G7 & 5.2 & Jun-2007 & 8.4 & Sep-2009 & 3.2 \\
\hline Slovak Republic & 8.9 & Sep-2008 & 12.0 & Sep-2009 & 3.1 \\
\hline Mexico & 3.2 & Dec-2005 & 6.1 & Sep-2009 & 2.9 \\
\hline OECD - Total & 5.7 & Apr-2008 & 8.6 & Sep-2009 & 2.9 \\
\hline Canada & 5.8 & Jan-2008 & 8.6 & Oct-2009 & 2.8 \\
\hline Sweden & 5.9 & Mar-2008 & 8.7 & Sep-2009 & 2.8 \\
\hline Czech Republic & 4.3 & Sep-2008 & 7.0 & Sep-2009 & 2.7 \\
\hline United Kingdom & 5.1 & Apr-2008 & 7.8 & Jul-2009 & 2.7 \\
\hline Hungary & 7.1 & Jul-2007 & 9.7 & Sep-2009 & 2.6 \\
\hline Luxembourg & 4.0 & Sep-2007 & 6.6 & Sep-2009 & 2.6 \\
\hline OECD - Europe & 6.9 & Apr-2008 & 9.4 & Sep-2009 & 2.5 \\
\hline European Union & 6.7 & Apr-2008 & 9.2 & Sep-2009 & 2.5 \\
\hline Euro area & 7.2 & Mar-2008 & 9.7 & Sep-2009 & 2.5 \\
\hline France & 7.6 & May-2008 & 10 & Sep-2009 & 2.4 \\
\hline Finland & 6.2 & May-2008 & 8.6 & Sep-2009 & 2.4 \\
\hline Australia & 3.9 & Feb-2008 & 5.8 & Oct-2009 & 1.9 \\
\hline Japan & 3.6 & Jul-2007 & 5.3 & Sep-2009 & 1.7 \\
\hline Greece & 7.5 & Sep-2008 & 9.2 & Jun-2009 & 1.7 \\
\hline Portugal & 7.6 & May-2008 & 9.2 & Sep-2009 & 1.6 \\
\hline Italy & 5.9 & Jun-2007 & 7.4 & Jun-2009 & 1.5 \\
\hline Poland & 6.8 & Oct-2008 & 8.2 & Sep-2009 & 1.4 \\
\hline Belgium & 6.6 & May-2008 & 7.9 & Sep-2009 & 1.3 \\
\hline Austria & 3.5 & Jun-2008 & 4.8 & Sep-2009 & 1.3 \\
\hline Norway & 2.3 & Mar-2008 & 3.2 & Aug-2009 & 0.9 \\
\hline Netherlands & 2.7 & Nov-2008 & 3.6 & Sep-2009 & 0.9 \\
\hline Korea & 3.0 & Jan-2008 & 3.6 & Sep-2009 & 0.6 \\
\hline Germany & 7.1 & Dec-2008 & 7.6 & Sep-2009 & 0.5 \\
\hline
\end{tabular}

Source: OECD 
Table 2. Youth unemployment rates and ratio to overall rates

\begin{tabular}{|l|c|c|c|c|c|}
\hline & \multicolumn{2}{|c|}{ Age $<25$} & \multicolumn{2}{c|}{ All } & Ratio<25/All \\
\hline & Sep-08 & Sep-09 & Sep-08 & Sep-09 & \\
\hline EA16 & 15.7 & 20.1 & 7.7 & 9.7 & 2.07 \\
\hline EU27 & 15.8 & 20.2 & 7.1 & 9.2 & 2.20 \\
\hline Austria & 7.9 & 9.9 & 3.9 & 4.8 & 2.06 \\
\hline Belgium & 19.9 & 20.9 & 7.3 & 7.9 & 2.65 \\
\hline Bulgaria & 11.2 & 16.8 & 5.2 & 7.6 & 2.21 \\
\hline Cyprus & 8.7 & 14.1 & 3.5 & 5.9 & 2.39 \\
\hline Czech Republic & 10.3 & 16.5 & 4.3 & 7.0 & 2.36 \\
\hline Denmark & 8.3 & 11.4 & 3.4 & 6.4 & 1.78 \\
\hline Finland & 17.0 & 22.8 & 6.5 & 8.6 & 2.65 \\
\hline France & 19.8 & 24.5 & 8.0 & 10.0 & 2.45 \\
\hline Germany & 9.5 & 10.4 & 7.1 & 7.6 & 1.37 \\
\hline Hungary & 20.0 & 25.2 & 7.8 & 9.7 & 2.60 \\
\hline Ireland & 14.2 & 27.6 & 6.7 & 13 & 2.12 \\
\hline Latvia & 12.9 & 33.6 & 8.1 & 19.7 & 1.71 \\
\hline Lithuania & 14.9 & 31.2 & 6.3 & 13.8 & 2.26 \\
\hline Luxembourg & 18.3 & 21.6 & 5.1 & 6.6 & 3.27 \\
\hline Malta & 11.2 & 14.8 & 5.8 & 7.2 & 2.06 \\
\hline Netherlands & 5.2 & 6.8 & 2.7 & 3.6 & 1.89 \\
\hline Poland & 16.6 & 20.5 & 6.8 & 8.2 & 2.50 \\
\hline Portugal & 17.3 & 18.6 & 7.8 & 9.2 & 2.02 \\
\hline Slovak Republic & 19.2 & 27.0 & 8.9 & 12.0 & 2.25 \\
\hline Slovenia & 10.2 & 11.7 & 4.1 & 5.9 & 1.98 \\
\hline Spain & 26.2 & 41.7 & 12.4 & 19.3 & 2.16 \\
\hline Sweden & 20.5 & 26.2 & 6.4 & 8.7 & 3.01 \\
\hline UK & 15.8 & 19.5 & 6.0 & 7.8 & 2.50 \\
\hline USA & 13.4 & 18.1 & 6.2 & 9.8 & 1.85 \\
\hline Sourc: EU & & & & & \\
\hline
\end{tabular}

Source: EU 


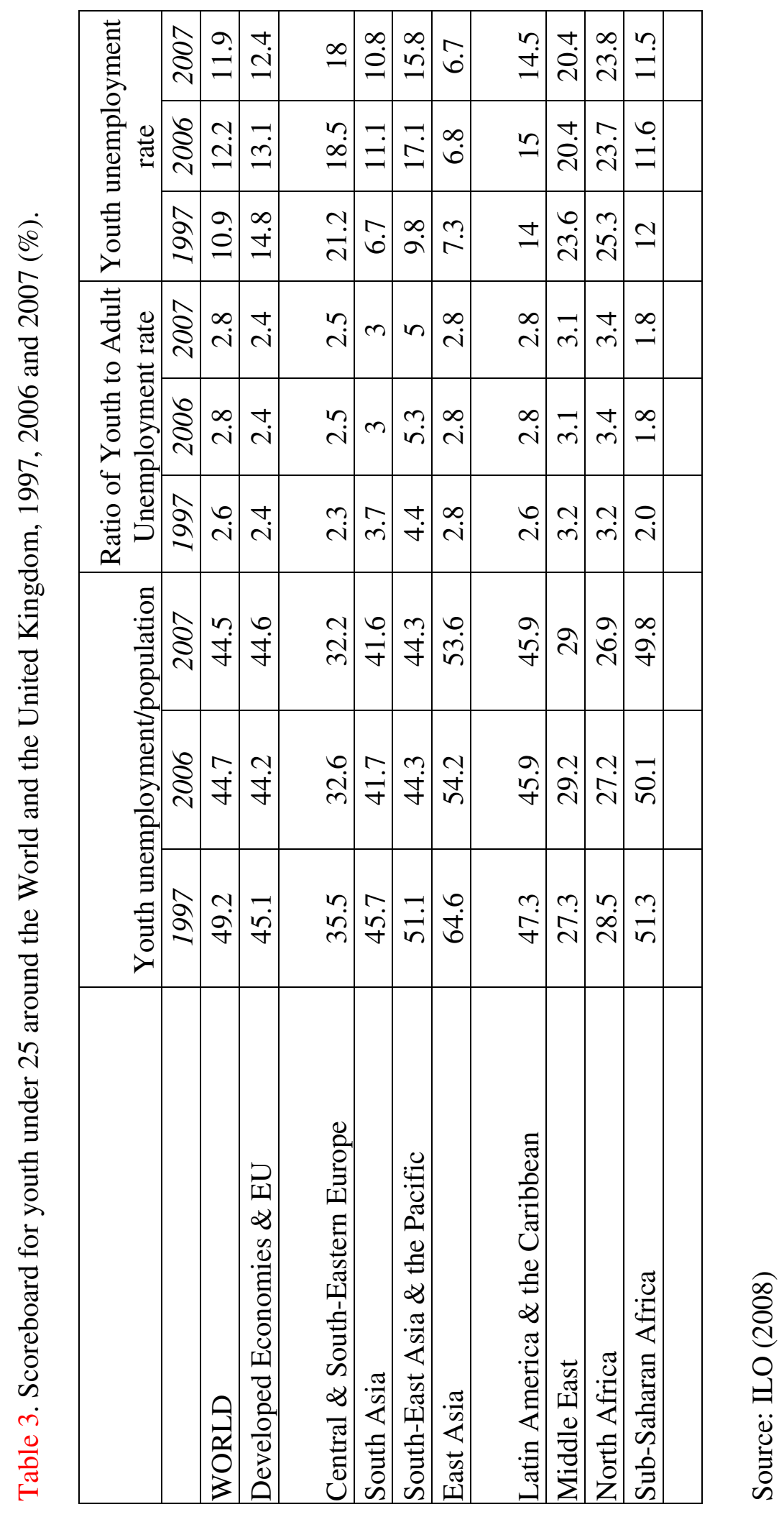



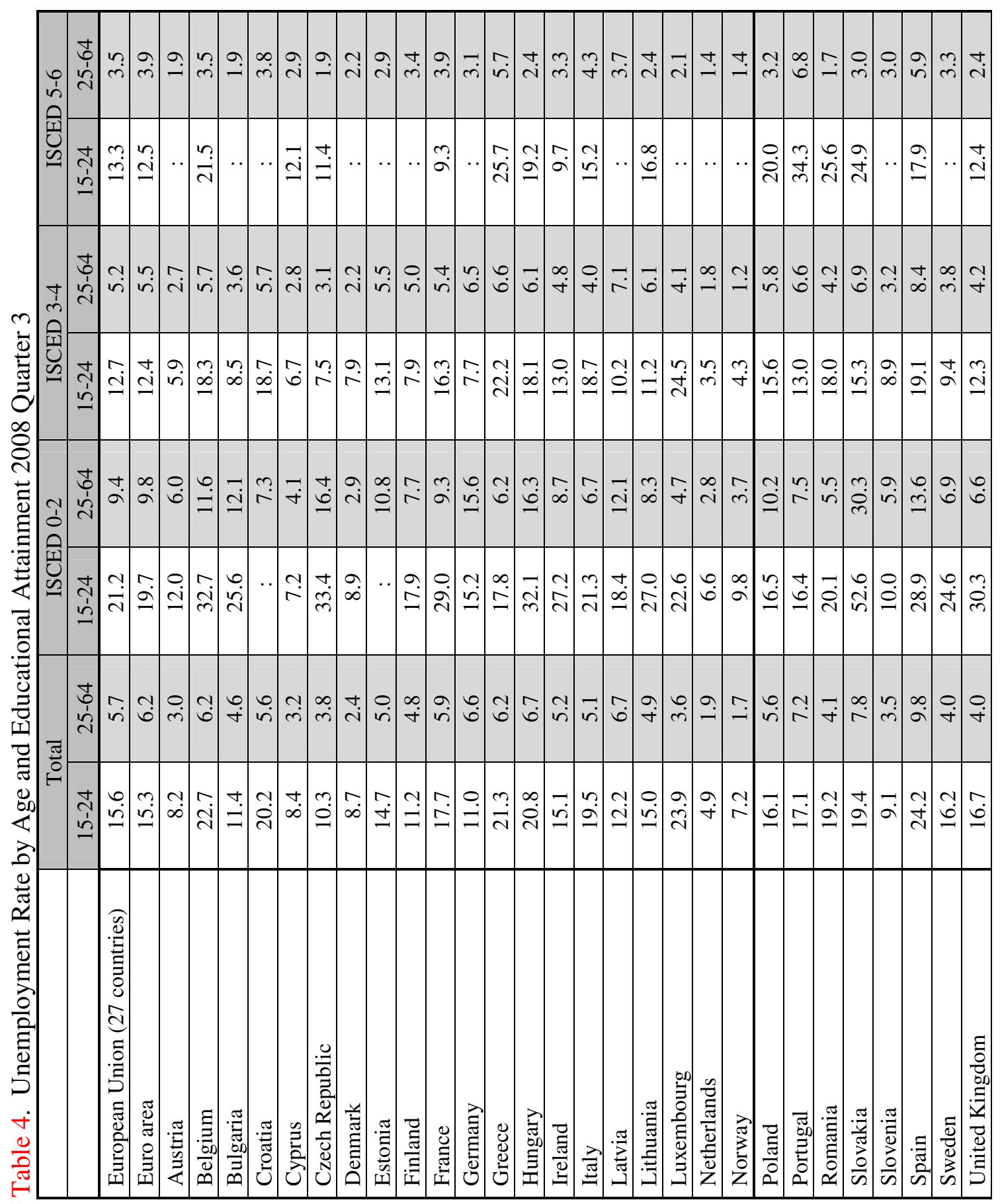


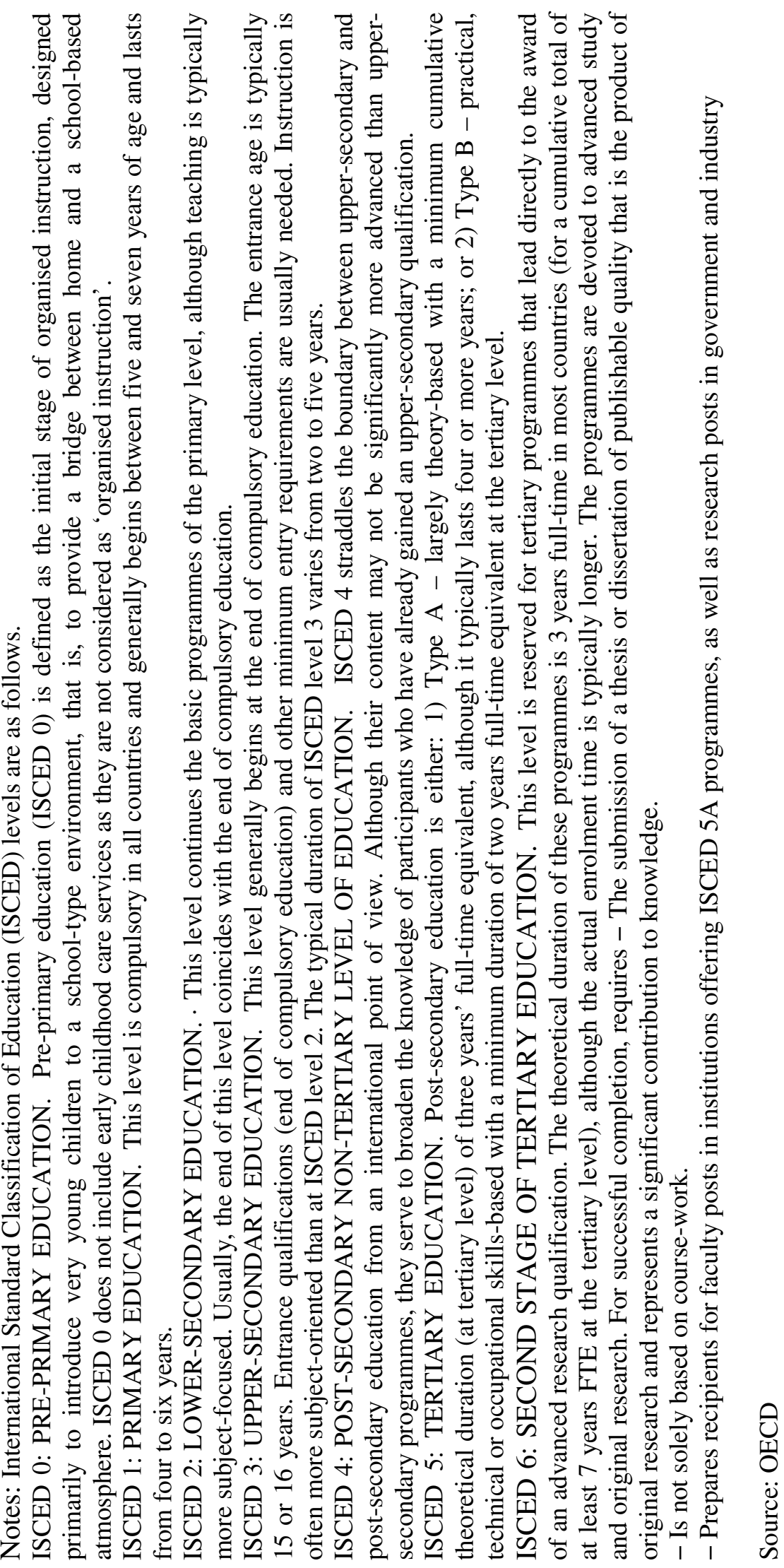




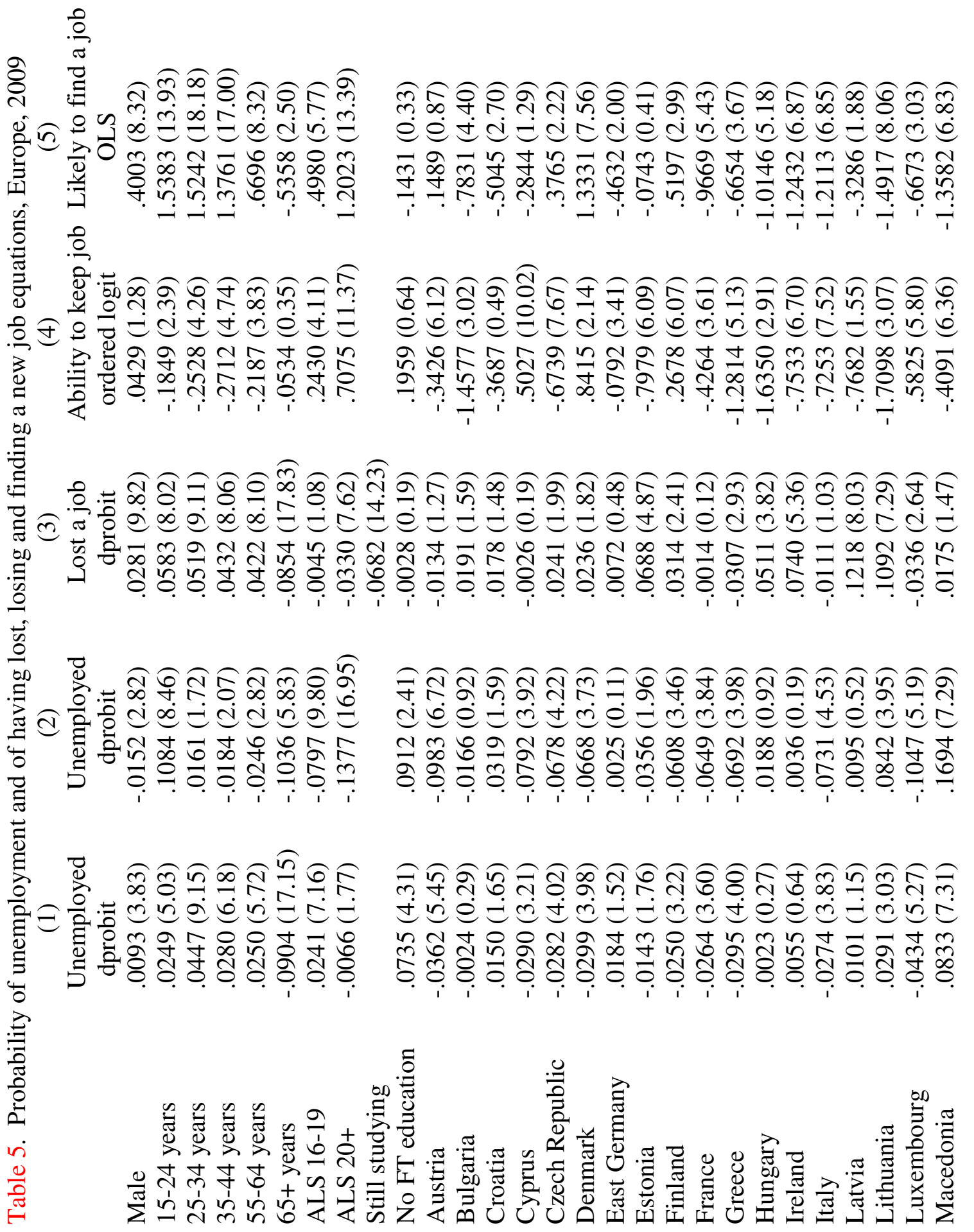




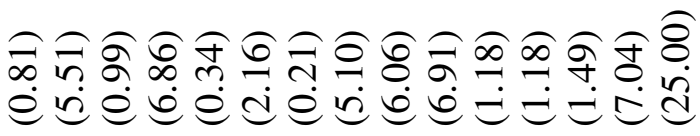

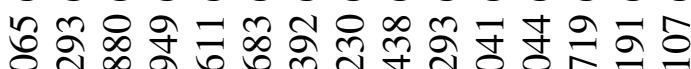

तิ

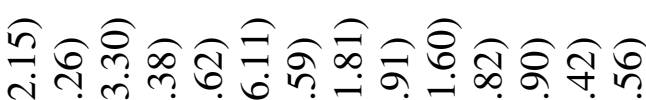

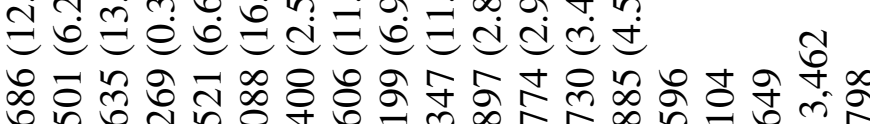

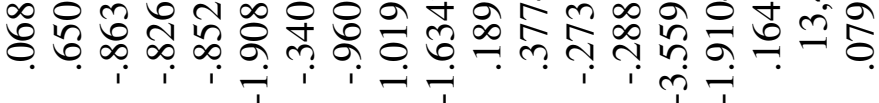

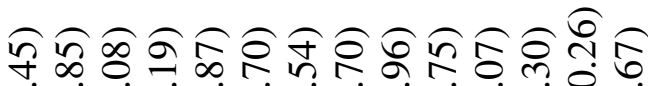

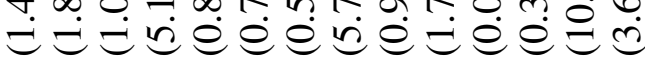

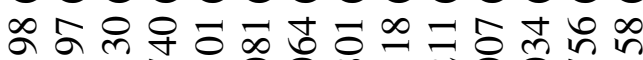
石

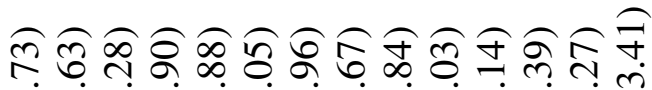

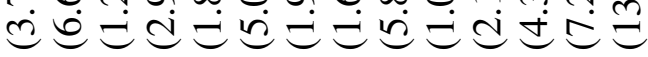

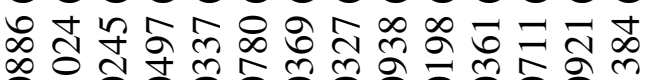
策

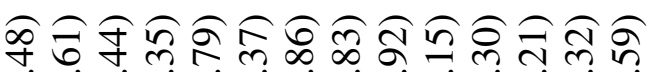
ن⿺辶寸

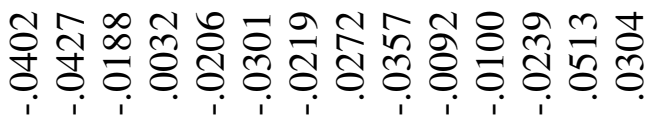

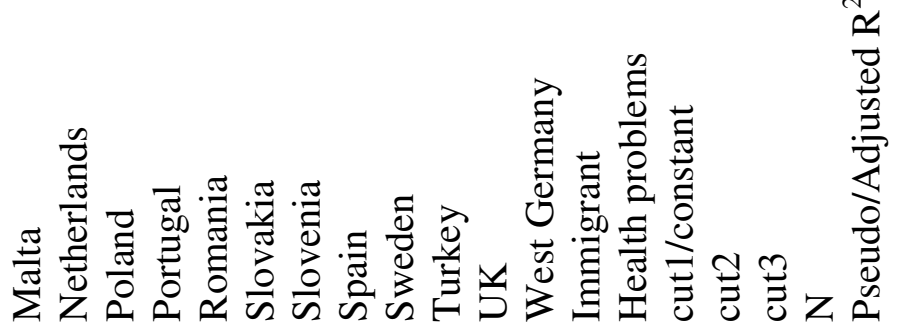

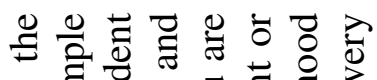

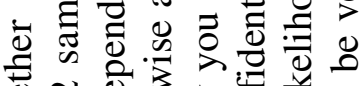

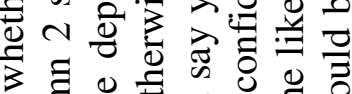

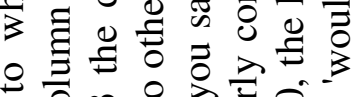

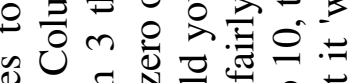

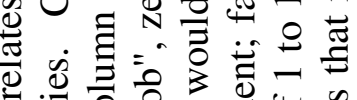

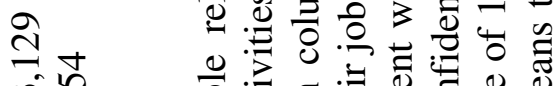

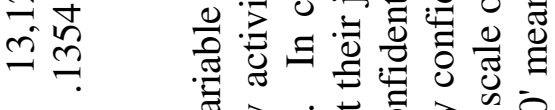

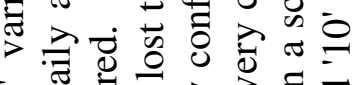

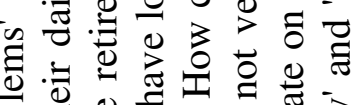

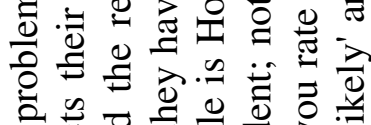

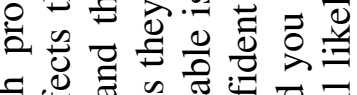

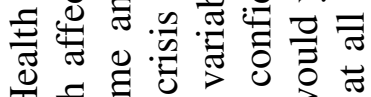
क्ष

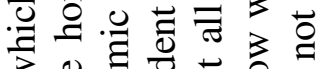
ن

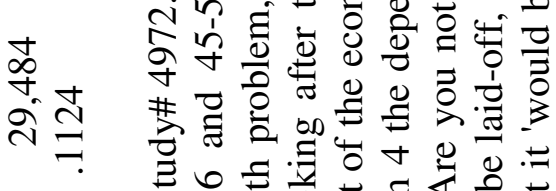

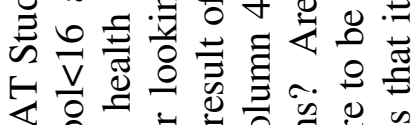

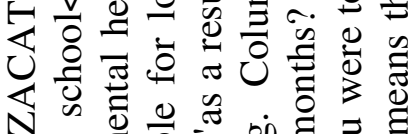
గ̂. Non

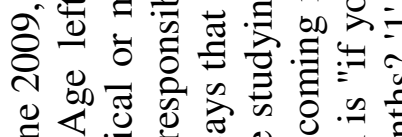

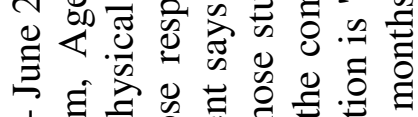

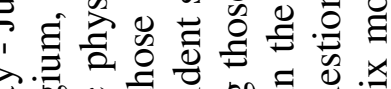

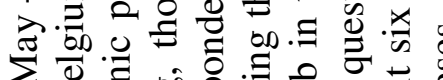

落 人。

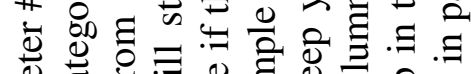

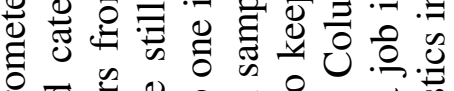

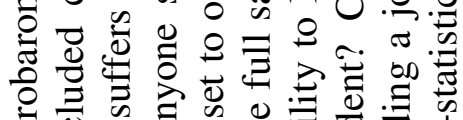

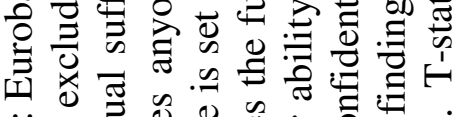

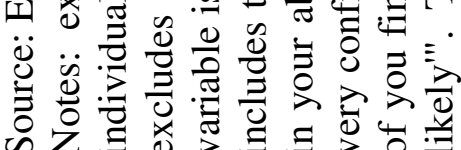


Table 6. Size of youth cohort in 2008 where the number of 20 year olds $=100$

\begin{tabular}{|c|c|c|c|c|c|}
\hline & $5 \mathrm{yrs}$ & $10 \mathrm{yrs}$ & $15 \mathrm{yrs}$ & $25 \mathrm{yrs}$ & \# Age 20 \\
\hline Euro area & 87.6 & 88.3 & 93.3 & 110.8 & $3,814,153$ \\
\hline Armenia & 50.0 & 70.2 & 93.7 & 91.7 & 63,333 \\
\hline Australia & 89.3 & 92.1 & 96.2 & 104.4 & 296,556 \\
\hline Austria & 81.5 & 88.2 & 99.4 & 111.7 & 100,537 \\
\hline Belarus & 53.9 & 54.1 & 77.0 & 97.4 & 162,934 \\
\hline Belgium & 90.7 & 95.0 & 102.4 & 105.3 & 127,376 \\
\hline Bulgaria & 64.5 & 57.4 & 80.0 & 104.7 & 103,028 \\
\hline Croatia & 73.0 & 92.7 & 88.4 & 112.2 & 55,644 \\
\hline Cyprus & 68.3 & 81.8 & 99.4 & 114.5 & 11,757 \\
\hline Czech Republic & 69.5 & 67.3 & 90.7 & 109.4 & 134,600 \\
\hline Denmark & 104.9 & 111.6 & 114.3 & 98.3 & 61,689 \\
\hline Estonia & 59.1 & 55.2 & 76.4 & 93.0 & 21,838 \\
\hline Finland & 90.8 & 96.8 & 109.2 & 111.6 & 61,957 \\
\hline France & 97.4 & 93.0 & 96.2 & 101.9 & 817,614 \\
\hline Georgia & 62.8 & 73.6 & 96.8 & 94.1 & 72,102 \\
\hline Germany & 73.6 & 83.1 & 85.8 & 102.7 & 982,931 \\
\hline Greece & 87.4 & 88.0 & 94.8 & 130.2 & 119,656 \\
\hline Hungary & 76.8 & 78.5 & 95.6 & 108.5 & 125,807 \\
\hline Iceland & 93.6 & 98.2 & 106.9 & 109.7 & 4,399 \\
\hline Ireland & 104.1 & 98.2 & 95.1 & 136.5 & 59,194 \\
\hline Italy & 93.8 & 93.0 & 100.2 & 115.1 & 591,715 \\
\hline Latvia & 52.8 & 48.6 & 79.6 & 91.8 & 37,681 \\
\hline Lithuania & 53.3 & 65.6 & 93.6 & 87.3 & 55,381 \\
\hline Luxembourg & 104.3 & 109.7 & 106.5 & 115.3 & 5,504 \\
\hline Macedonia & 68.8 & 77.7 & 93.5 & 100.0 & 33,263 \\
\hline Moldova & 49.3 & 58.4 & 80.2 & 82.3 & 73,876 \\
\hline Montenegro & 80.4 & 82.1 & 90.7 & 100.9 & 10,053 \\
\hline Netherlands & 101.2 & 97.9 & 101.3 & 97.3 & 198,534 \\
\hline Norway & 98.5 & 107.1 & 108.8 & 100.2 & 58,239 \\
\hline Poland & 60.7 & 70.2 & 87.0 & 113.6 & 579,666 \\
\hline Portugal & 94.3 & 88.4 & 93.8 & 124.6 & 120,091 \\
\hline Romania & 58.5 & 62.2 & 71.1 & 89.0 & 352,397 \\
\hline Russian Federation & 53.7 & 49.9 & 65.4 & 96.6 & $2,556,769$ \\
\hline Serbia & 81.6 & 78.0 & 87.4 & 106.2 & 95,973 \\
\hline Slovakia & 61.1 & 70.1 & 89.4 & 109.8 & 82,551 \\
\hline Slovenia & 67.7 & 70.1 & 76.8 & 111.0 & 26,541 \\
\hline Spain & 88.9 & 81.6 & 86.8 & 131.5 & 502,550 \\
\hline Sweden & 86.2 & 82.4 & 110.5 & 94.9 & 115,360 \\
\hline Switzerland & 84.1 & 92.3 & 102.2 & 106.9 & 88,726 \\
\hline Ukraine & 51.7 & 57.4 & 76.6 & 97.8 & 744,442 \\
\hline United Kingdom & 80.9 & 89.4 & 96.1 & 97.6 & 820,200 \\
\hline USA & 96.7 & 94.2 & 102.3 & 102.8 & $4,168,920$ \\
\hline
\end{tabular}


Table 7. Labour market status of 16-24 year olds, USA, 2006-2009 (July)

\begin{tabular}{|c|c|c|c|c|}
\hline & 2006 & 2007 & 2008 & 2009 \\
\hline \multicolumn{5}{|l|}{ All } \\
\hline Civilian non-institutional population. & 36,989 & 37,443 & 37,506 & 37,586 \\
\hline 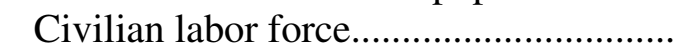 & 24,664 & 24,339 & 24,429 & 23,691 \\
\hline Participation rate.......... & 66.7 & 65.0 & 65.1 & 63.0 \\
\hline Employed... & 21,914 & 21,717 & 21,021 & 19,304 \\
\hline Employment-population ratio.. & $\ldots . . .59 .2$ & 58.0 & 56.0 & 51.4 \\
\hline 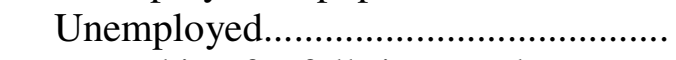 & 2,750 & 2,622 & 3,408 & 4,387 \\
\hline Looking for full-time work & 2,028 & 1,892 & 2,552 & 3,430 \\
\hline Looking for part-time work & 722 & 730 & 856 & 957 \\
\hline Unemployment rate & 11.2 & 10.8 & 14.0 & 18.5 \\
\hline Not in labor force & 12,324 & 13,104 & 13,076 & 13,895 \\
\hline \multicolumn{5}{|l|}{ Men } \\
\hline Civilian non-institutional population & 18,675 & 18,926 & 18,919 & 18,935 \\
\hline Civilian labor force & 13,024 & 12,845 & 12,882 & 12,298 \\
\hline Participation rate & 69.7 & 67.9 & 68.1 & 64.9 \\
\hline Employed & 11,568 & 11,421 & 10,946 & 9,880 \\
\hline Employmen & ........61.9 & 60.3 & 57.9 & 52.2 \\
\hline Unemployed & 1,456 & 1,424 & 1,935 & 2,418 \\
\hline Looking for full-time work & 1,152 & 1,059 & 1,483 & 1,973 \\
\hline Looking for part-time work & 303 & 365 & 453 & 444 \\
\hline Unemployment rate & 11.2 & 11.1 & 15.0 & 19.7 \\
\hline Not in labor force & 5,651 & 6,081 & 6,037 & 6,637 \\
\hline
\end{tabular}

\section{Women}

Civilian non-institutional population $18,31418,517$

18,587

18,650

Civilian labor force Participation rate

$\begin{array}{rr}11,641 & 11,494 \\ 63.6 & 62.1\end{array}$

$11,547 \quad 11,393$

Employed

$10,346 \quad 10,296$

Employment-population ratio

.56 .5

Unemployed

1,295

55.6

Looking for full-time work

Looking for part-time work

Unemployment rate

876

1,198

833

419

365

11.1

10.4

62.1

61.1

$10,075 \quad 9,424$

Not in labor force

$$
6,673
$$

7,023

54.2

1,473

1,969

$1,070 \quad 1,456$

$403 \quad 513$

$12.8 \quad 17.3$

7,039

7,257

\section{White}

Civilian non-institutional population.

Civilian labor force

Participation rate

Employed

Employment-population ratio.

Unemployed

Looking for full-time work n..................

$\begin{array}{cr}20,002 & 19,734 \\ 69.6 & 68 \\ 18,193 & 17,899\end{array}$

63

61.7

29,012

29,010

$19,760 \quad 19,147$

$68.1 \quad 66$

$17,323 \quad 16,000$

$1,808 \quad 1,835$

59.7

55.2

$2,437 \quad 3,147$

$1,759 \quad 2,403$ 
Looking for part-time work

Unemployment rate

Not in labor force

\section{Black or African American}

Civilian non-institutional population

Civilian labor force.

Participation rate

Employed

Employment-population ratio

Unemployed

Looking for full-time work

Looking for part-time work

Unemployment rate

Not in labor force

$\begin{array}{cccc}520 & 531 & 678 & 744 \\ 9.0 & 9.3 & 12.3 & 16.4 \\ 8,735 & 9,278 & 9,252 & 9,863\end{array}$

5,426

5,539

5,595

5,662

$3,133 \quad 2,998 \quad 3,062 \quad 2,995$

$\begin{array}{rrrr}57.7 & 54.1 & 54.7 & 52.9\end{array}$

$2,361 \quad 2,382 \quad 2,302 \quad 2,060$

$\begin{array}{llll}. .43 .5 & 43.0 & 41.2 & 36.4\end{array}$

$\begin{array}{llll}772 & 616 & 760 & 935\end{array}$

$\begin{array}{llll}617 & 488 & 647 & 772\end{array}$

$\begin{array}{llll}155 & 128 & 112 & 163\end{array}$

$24.7 \quad 20.5 \quad 24.8 \quad 31.2$

$2,293 \quad 2,541 \quad 2,533 \quad 2,667$

$\begin{array}{lcccc}\text { Asian } & & & & \\ \text { Civilian non-institutional population..... } & 1,474 & 1,511 & 1,516 & 1,500 \\ \text { Civilian labor force } & 687 & 747 & 767 & 740 \\ \quad \text { Participation rate } & 46.6 & 49.4 & 50.6 & 49.3 \\ \text { Employed } & 631 & 689 & 703 & 619 \\ \quad \text { Employment-population ratio................42.8 } & 45.6 & 46.4 & 41.3 \\ \text { Unemployed } & 56 & 58 & 64 & 121 \\ \text { Looking for full-time work } & 33 & 32 & 38 & 96 \\ \text { Looking for part-time work } & 23 & 26 & 26 & 24 \\ \text { Unemployment rate } & 8.2 & 7.7 & 8.4 & 16.3 \\ \text { Not in labor force } & 787 & 764 & 748 & 760 \\ & & & & \\ \text { Hispanic or Latino ethnicity } & & & & \\ \text { Civilian non-institutional population } & 6,406 & 6,597 & 6,669 & 6,752 \\ \text { Civilian labor force } & 3,943 & 3,928 & 4,007 & 4,014 \\ \text { Participation rate } & 61.5 & 59.5 & 60.1 & 59.4 \\ \text { Employed } & 3,534 & 3,465 & 3,367 & 3,143 \\ \text { Employment-population ratio...............55.2 } & 52.5 & 50.5 & 46.5 \\ \text { Unemployed } & 409 & 464 & 639 & 871 \\ \text { Looking for full-time work } & 287 & 341 & 487 & 693 \\ \text { Looking for part-time work } & 122 & 123 & 153 & 178 \\ \text { Unemployment rate } & 10.4 & 11.8 & 16 & 21.7 \\ \text { Not in labor force } & 2,463 & 2,669 & 2,662 & 2,738\end{array}$

Source: 'Employment and unemployment among youth -- Summer 2009', Bureau of Labor Statistics, http://www.bls.gov/news.release/youth.nr0.htm 
Table 8. Probability of being unemployed ages 16-24 USA, 1979-2009 (dprobits)

\begin{tabular}{|c|c|c|c|c|}
\hline \multirow[b]{2}{*}{ 1983/2008 dummy } & \multirow[t]{2}{*}{1979} & 1982-1983 & 2007-2008 & \multirow[t]{2}{*}{2009} \\
\hline & & $-.0030(1.26)$ & .0210 (8.55) & \\
\hline 17 years of age & $-.0133(2.31)$ & .0043 (0.74) & $-.0176(2.99)$ & $-.0235(3.47)$ \\
\hline 18 years of age & $-.0125(2.18)$ & - & $-.0015(0.25)$ & $.0365(4.77)$ \\
\hline 19 years of age & $-.0243(4.32)$ & $-.0112(2.00)$ & $-.0066(1.01)$ & $.0302(3.88)$ \\
\hline 20 years of age & $-.0383(6.89)$ & $-.0277(5.03)$ & $-.0184(2.85)$ & $.0045(0.60)$ \\
\hline 21 years of age & $-.0423(7.71)$ & $-.0425(7.85)$ & $-.0331(5.35)$ & $-.0071(0.96)$ \\
\hline 22 years of age & $-.0565(10.50)$ & $-.0481(8.96)$ & $-.0310(4.98)$ & $-.0164(2.24)$ \\
\hline 23 years of age & $-.0596(11.11)$ & $-.0549(10.27)$ & $-.0401(6.61)$ & $-.0247(3.41)$ \\
\hline 24 years of age & $-.0654(12.25)$ & $-.0597(11.22)$ & $-.0454(7.55)$ & $-.0406(5.73)$ \\
\hline Male & $-.0109(3.94)$ & $.0172(7.16)$ & $.0191(7.69)$ & $.0389(15.21)$ \\
\hline Black & $.1681(28.89)$ & .2338 (46.99) & .0976 (19.53) & . $1366(27.40)$ \\
\hline Other race & $.0371(3.72)$ & $.0883(10.39)$ & $.0161(1.84)$ & $.0742(8.36)$ \\
\hline Hispanic & $.0214(3.17)$ & $.0542(9.24)$ & $.0121(3.09)$ & $.0206(5.05)$ \\
\hline Native American & & & $.0800(5.19)$ & $.0919(7.11)$ \\
\hline Asian & & & $-.0231(2.89)$ & $.0083(1.04)$ \\
\hline Hawaiian & & & $.0390(1.88)$ & . 0769 (3.76) \\
\hline Years of schooling & $-.0129(15.50)$ & $-.0247(34.29)$ & $\mathrm{n} / \mathrm{a}$ & $\mathrm{n} / \mathrm{a}$ \\
\hline 1/2/3/4th Grade & & $-.0350(0.93)$ & $-.0563(1.19)$ & \\
\hline 5th or 6th Grade & & & $-.0384(1.20)$ & $.0203(0.47)$ \\
\hline 7th or 8th Grade & & & $.0583(1.32)$ & - \\
\hline 9th Grade & & & .0698 (1.58) & 焉. $1871(3.76)$ \\
\hline 10th Grade & & & $.0344(0.87)$ & . $1502(3.19)$ \\
\hline 11th Grade & & & $.0073(0.20)$ & .0861 (1.98) \\
\hline 12th Grade No Dipl & $\mathrm{ma}$ & & $-.0072(0.21)$ & .0974 (2.15) \\
\hline High School Diplon & & & $-.0145(0.42)$ & $.0462(1.16)$ \\
\hline Some College & & & $-.0569(1.76)$ & $-.0304(0.82)$ \\
\hline Associate Degree - & Dccup. & & $-.0512(1.79)$ & $-.0451(1.28)$ \\
\hline Associate Degree - & Acad. & & $-.0670(2.64)$ & $-.0461(1.31)$ \\
\hline Bachelor's Degree & & & $-.0528(1.81)$ & $-.0365(1.01)$ \\
\hline Master's Degree & & & $-.0540(1.74)$ & $-.0364(0.92)$ \\
\hline Professional Degree & & & $-.0474(0.89)$ & $-.0060(0.09)$ \\
\hline Alabama & $-.0410(2.93)$ & $-.0337(3.35)$ & $-.0276(2.24)$ & $-.0155(1.18)$ \\
\hline Alaska & $-.0107(0.68)$ & $-.0696(7.27)$ & $-.0243(2.20)$ & $-.0778(7.12)$ \\
\hline Arizona & $-.0526(3.58)$ & $-.0475(4.54)$ & $-.0290(2.50)$ & $-.0160(1.20)$ \\
\hline Arkansas & $-.0495(3.31)$ & $-.0558(5.37)$ & $-.0313(2.61)$ & $-.0466(3.56)$ \\
\hline California & $-.0379(3.22)$ & -.0653 (10.29) & $-.0058(0.70)$ & $.0035(0.40)$ \\
\hline Colorado & $-.0500(3.80)$ & $-.0827(9.24)$ & $-.0306(3.11)$ & $-.0428(4.09)$ \\
\hline Connecticut & -.0247 (1.97) & $-.0814(7.53)$ & $-.0244(2.43)$ & $-.0547(5.40)$ \\
\hline D.C. & $-.0534(2.84)$ & $-.0699(5.96)$ & $-.0283(2.48)$ & $-.0117(0.86)$ \\
\hline Delaware & $-.0078(0.42)$ & $-.0516(4.53)$ & $-.0542(5.54)$ & $-.0515(4.59)$ \\
\hline Florida & $-.0485(3.98)$ & $-.0856(11.75)$ & $-.0359(4.25)$ & $-.0325(3.42)$ \\
\hline Georgia & $-.0593(4.86)$ & $-.0940(11.43)$ & $-.0123(1.19)$ & $-.0289(2.61)$ \\
\hline Hawaii & $-.0096(0.49)$ & $-.0985(8.62)$ & $-.0301(2.46)$ & $-.0576(4.70)$ \\
\hline Idaho & $-.0415(2.77)$ & $-.0396(3.58)$ & $-.0325(2.88)$ & $-.0151(1.18)$ \\
\hline Illinois & $-.0265(2.08)$ & $-.0468(6.15)$ & $-.0214(2.37)$ & $-.0200(2.03)$ \\
\hline Indiana & $-.0472(4.00)$ & $-.0299(3.22)$ & $-.0175(1.53)$ & $-.0037(0.30)$ \\
\hline
\end{tabular}




\begin{tabular}{|c|c|c|c|c|}
\hline Iowa & $-.0627(4.88)$ & $-.0734(8.01)$ & $-.0540(6.19)$ & $-.0589(5.90)$ \\
\hline Kansas & $-.0761(5.93)$ & $-.0944(9.40)$ & $-.0355(3.43)$ & $-.0600(5.58)$ \\
\hline Kentucky & $-.0255(1.68)$ & $-.0246(2.28)$ & $-.0207(1.81)$ & $-.0031(0.25)$ \\
\hline Louisiana & $-.0338(2.39)$ & $-.0640(6.65)$ & $-.0541(4.38)$ & $-.0554(4.11)$ \\
\hline Maine & $-.0752(5.00)$ & $-.0490(4.56)$ & $-.0223(2.16)$ & $-.0074(0.65)$ \\
\hline Maryland & $-.0506(3.91)$ & $-.0816(9.40)$ & $-.0436(4.81)$ & $-.0653(6.82)$ \\
\hline Massachusetts & $-.0246(1.34)$ & $-.0693(8.46)$ & $-.0393(3.58)$ & $-.0488(4.20)$ \\
\hline Minnesota & $-.0477(3.68)$ & $-.0726(8.45)$ & $-.0231(2.49)$ & $-.0350(3.50)$ \\
\hline Mississippi & $-.0620(4.66)$ & $-.0320(2.94)$ & $-.0161(1.22)$ & $-.0551(3.94)$ \\
\hline Missouri & $-.0606(4.90)$ & $-.0592(6.35)$ & $-.0254(2.41)$ & $-.0379(3.50)$ \\
\hline Montana & $-.0459(3.10)$ & $-.0672(6.57)$ & $-.0232(1.84)$ & $-.0607(4.43)$ \\
\hline Nebraska & $-.0726(5.32)$ & -.0877 (8.92) & $-.0577(6.20)$ & $-.0996(10.31)$ \\
\hline Nevada & $-.0670(4.69)$ & $-.0701(6.39)$ & $-.0368(3.52)$ & $-.0138(1.11)$ \\
\hline New Hampshire & $-.0362(2.15)$ & $-.0882(8.11)$ & $-.0361(3.82)$ & $-.0596(5.81)$ \\
\hline New Jersey & $-.0234(1.82)$ & $-.0612(7.56)$ & $-.0237(2.22)$ & $-.0321(2.89)$ \\
\hline New Mexico & $-.0158(0.96)$ & $-.0587(5.50)$ & $-.0415(3.16)$ & $-.0618(4.26)$ \\
\hline New York & $-.0310(2.34)$ & $-.0551(7.94)$ & $-.0135(1.50)$ & $-.0250(2.66)$ \\
\hline North Carolina & $-.0659(5.57)$ & $-.0657(7.23)$ & $-.0329(3.32)$ & $-.0264(2.40)$ \\
\hline North Dakota & $-.0685(5.14)$ & $-.0879(9.06)$ & $-.0626(6.50)$ & $-.0980(9.09)$ \\
\hline Ohio & $-.0310(2.33)$ & $-.0207(2.62)$ & $-.0140(1.49)$ & $-.0281(2.87)$ \\
\hline Oklahoma & $-.0673(4.46)$ & $-.0843(8.98)$ & $-.0503(4.65)$ & $-.0825(7.30)$ \\
\hline Oregon & $-.0339(2.22)$ & $-.0194(1.71)$ & $-.0184(1.53)$ & $.0115(0.89)$ \\
\hline Pennsylvania & $-.0379(3.10)$ & $-.0326(4.19)$ & $-.0207(2.26)$ & $-.0548(6.03)$ \\
\hline Rhode Island & $-.0389(2.66)$ & $-.0542(4.83)$ & $-.0099(0.92)$ & $.0047(0.40)$ \\
\hline South Carolina & $-.0668(4.84)$ & $-.0841(8.38)$ & -.0231 (1.99) & $-.0392(3.20)$ \\
\hline South Dakota & $-.0705(5.52)$ & $-.0929(10.18)$ & $-.0645(7.04)$ & $-.0920(9.16)$ \\
\hline Tennessee & $-.0417(3.01)$ & $-.0360(3.51)$ & $-.0177(1.46)$ & $-.0119(0.95)$ \\
\hline Texas & $-.0721(6.95)$ & $-.0910(14.17)$ & $-.0422(5.41)$ & $-.0646(7.81)$ \\
\hline Utah & $-.0599(4.58)$ & $-.0680(7.32)$ & $-.0654(6.91)$ & $-.0473(4.15)$ \\
\hline Vermont & $-.0396(3.09)$ & $-.0656(5.81)$ & $-.0297(2.69)$ & $-.0524(4.63)$ \\
\hline Virginia & $-.0604(4.90)$ & $-.0763(8.68)$ & $-.0557(6.16)$ & $-.0570(5.46)$ \\
\hline Washington & $-.0274(1.85)$ & $-.0288(2.72)$ & $-.0185(1.72)$ & $-.0214(1.89)$ \\
\hline West Virginia & -.0037 (0.20) & $.0531(4.06)$ & $-.0292(2.27)$ & $-.0206(1.44)$ \\
\hline Wisconsin & $-.0516(4.06)$ & $-.0342(3.65)$ & $-.0298(3.08)$ & $-.0487(4.78)$ \\
\hline Wyoming & $-.0617(4.27)$ & $-.0706(6.23)$ & $-.0613(6.16)$ & $-.0717(6.67)$ \\
\hline $\mathrm{N}$ & 49,519 & 95,521 & 56,412 & 83,552 \\
\hline Pseudo $\mathrm{R}^{2}$ & .0606 & .0685 & .0660 & .0625 \\
\hline
\end{tabular}

Notes: excluded categories 16 years of age; $1^{\text {st }}$ grade, Michigan and white

Columns 1-3 use Matched Outgoing Rotation Group files of the CPS while column 4 uses the Basic Monthly Files, January -September. T-statistics in parentheses. Sample is the workforce (employed + unemployed). 
Table 9. Probability of being unemployed in the UK, ages < 25, 1981-1986 (dprobits)

1981

Age 17

Age 18

Age 19

Age 20

Age 21

Age 22

Age 23

Age 24

Male

Teaching, nursing

Apprentices

A level

O level

None

Education dk

Mixed race

Black

Asian

Other

Yorkshire \& Humberside

East Midlands

East Anglia

South East

South West

West Midlands

North West

Wales

Scotland

Northern Ireland

$\mathrm{N}$

Pseudo $\mathrm{R}^{2}$
$-.0223(1.50)$

$-.0625(5.52)$

$-.0677(6.16)$

$-.0664(5.77)$

$-.0704(6.42)$

$-.0679(6.19)$

$-.0750(7.20)$

$-.0724(6.82)$

$-.0286(7.45)$

$-.0362(2.01)$

$-.0398(2.56)$

$-.0197(1.13)$

$.0174(0.96)$

.0879 (4.14)

$.0751(2.57)$

.0920 (3.06)

.1877 (9.19)

$.0630(4.00)$

$.0476(1.72)$

$-.0236(2.98)$

-.0385 (4.91)

$-.0400(3.98)$

$-.0576(8.66)$

$-.0386(4.94)$

$-.0120(1.48)$

$.0000(0.00)$

$-.0088(0.92)$

$-.0041(0.49)$

$-.0272(1.29)$

18917

.1097

\section{3-1986}

-.0330 (4.77)

$-.0242(3.59)$

$-.0513(7.89)$

-.0585 (9.05)

$-.0625(9.68)$

-.0760 (11.92)

$-.0821(12.82)$

-.0898 (14.07)

-.0374 (12.23)

$-.0781(6.09)$

$-.0474(4.52)$

$-.0199(1.84)$

$.0192(1.87)$

.1914 (15.52)

.1049 (8.31)

.1558 (5.37)

.2033 (14.61)

.1352 (10.67)

$.0248(2.25)$

$-.0432(6.10)$

$-.0786(10.85)$

-.0871 (10.29)

-.1142 (19.00)

-.0839 (11.78)

$-.0387(5.41)$

$-.0196(2.76)$

-.0115 (1.33)

$-.0281(3.90)$

-.0354 (2.88)

68,503

.0685

Source: Labour Force Surveys, 1981, 1982-1984

Notes: excluded categories: white; degree or higher and age 16. Sample is the workforce (employed + unemployed). T-statistics in parentheses. 
Table 10. Probability of being unemployed, UK Q1 2006 - Q3 2009 (LFS) if age $<25$ (dprobits)

2008 dummy

17 years of age

18 years of age

19 years of age

20 years of age

21 years of age

22 years of age

23 years of age

24 years of age

Male

Higher education

A-level

GCSE A-C

Other qualifications

No qualification

DK qualification

Immigrant

Mixed race

Asian

Black

Chinese

Other race

Rest of North

South Yorkshire

West Yorkshire

Rest of Yorkshire

East Midlands

East Anglia

Inner London

Outer London

Rest of South East

South West

West Midlands

Rest West Midlands

Greater Manchester

Merseyside

Rest North West

Wales

Strathclyde

Rest Scotland

Northern Ireland

$\mathrm{N}$

Pseudo $\mathrm{R}^{2}$
Q1 2006-Q1 2008

$-.0058(1.48)$

$-.0336(7.07)$

$-.0421(8.99)$

$-.0541(11.58)$

-.0728 (16.09)

-.0857 (19.57)

-.0916 (21.06)

-.1097 (26.14)

-.1133 (27.09)

.0284 (11.38)

$-.0274(3.49)$

$-.0340(6.59)$

$.0155(2.89)$

.1072 (14.98)

.1807 (22.58)

$.0614(3.73)$

$-.0269(5.72)$

$.0801(7.03)$

$.1266(17.49)$

$.1979(17.60)$

$.1084(4.53)$

.0785 (5.94)

$-.0058(0.58)$

$-.0038(0.34)$

$-.0149(1.57)$

$-.0283(2.81)$

$-.0150(1.71)$

$-.0303(3.22)$

$.0416(3.59)$

$.0025(0.27)$

$-.0315(3.91)$

$-.0480(5.93)$

$.0110(1.08)$

$-.0262(2.81)$

$-.0114(1.19)$

$.0338(2.73)$

$-.0303(3.26)$

$-.0119(1.27)$

$-.0051(0.51)$

$-.0069(0.72)$

$-.0433(4.72)$

73,205

.0906
Q2 2008-Q3 2009

-.0401 (11.31)

$-.0615(8.84)$

$-.0678(9.82)$

$-.0822(12.01)$

-.0921 (13.58)

-.1055 (16.11)

-.1167 (18.16)

-.1418 (23.06)

$-.1570(26.21)$

.0435 (12.19)

$-.0441(4.15)$

$-.0564(8.19)$

$.0015(0.21)$

.1005 (10.77)

.1599 (15.43)

$.0403(1.80)$

$-.0459(6.81)$

.0865 (5.67)

$.1176(11.71)$

$.1950(12.42)$

.0919 (2.68)

.1016 (5.46)

$-.0391(2.89)$

$-.0123(0.80)$

$-.0474(3.74)$

$-.0550(4.04)$

$-.0639(5.63)$

$-.0684(5.52)$

$-.0199(1.38)$

$-.0401(3.20)$

$-.0742(6.85)$

$-.0880(8.19)$

$-.0012(0.09)$

$-.0615(5.03)$

$-.0257(1.97)$

$.0191(1.12)$

$-.0537(4.26)$

-.0396 (3.09)

-.0594 (4.64)

$-.0558(4.43)$

-.0604 (4.76)

44,203

.0868

Notes: excluded categories: Tyne and Wear; degree and white. T-statistics in parentheses

Sample is the workforce (employed + unemployed) 
Table 11. Life satisfaction and job situation equations, Europe, 2009 (ordered logits)

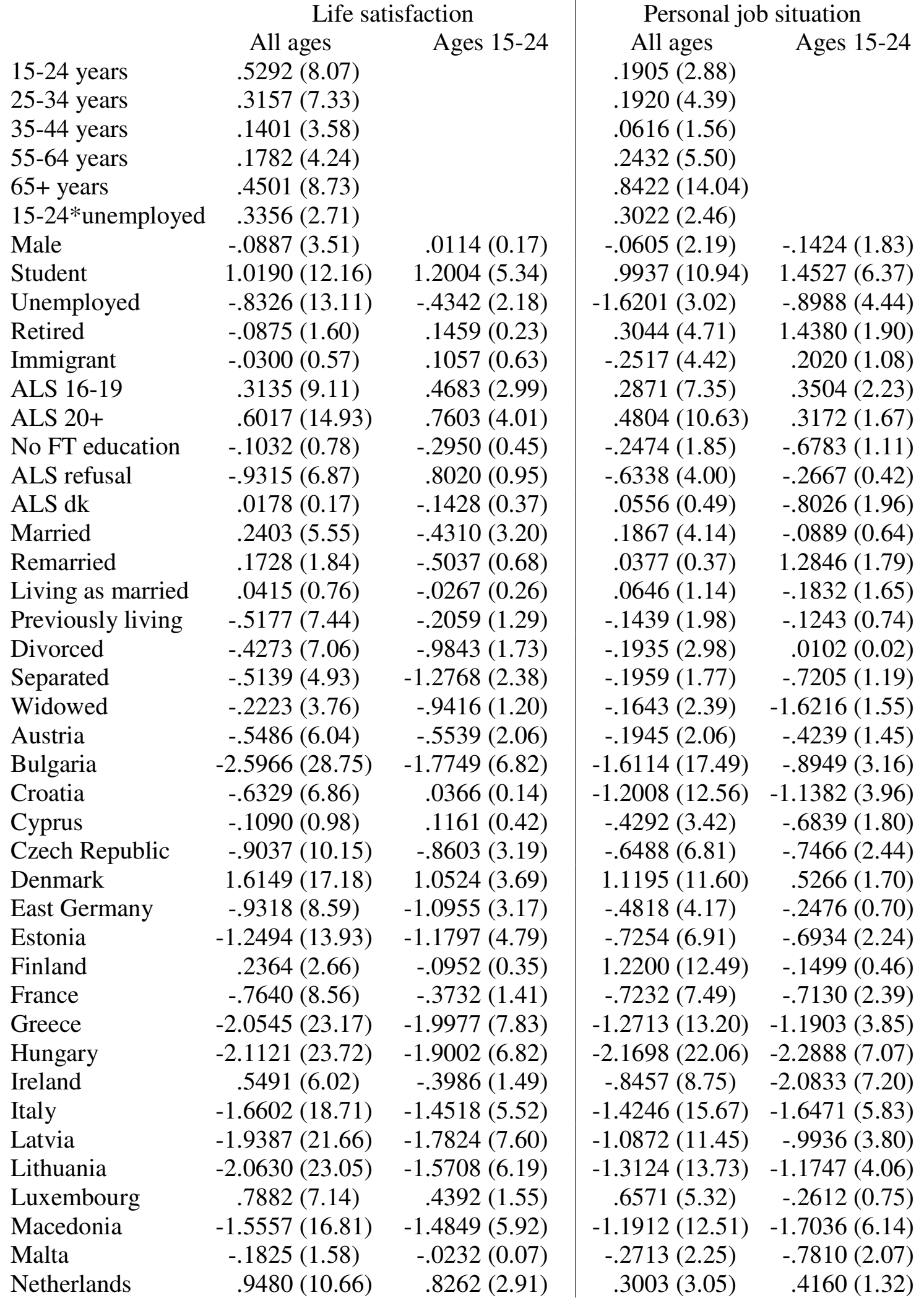




\begin{tabular}{lcc|cr} 
Poland & $-1.1120(12.28)$ & $-.9892(4.07)$ & $-.8536(8.99)$ & $-.6407(2.37)$ \\
Portugal & $-1.9456(21.60)$ & $-1.4846(6.02)$ & $-1.2919(13.37)$ & $-1.2939(4.74)$ \\
Romania & $-1.9955(22.32)$ & $-1.6163(6.26)$ & $-1.3819(13.80)$ & $-1.2968(4.20)$ \\
Slovakia & $-1.1799(13.20)$ & $-.8552(3.13)$ & $-1.1532(12.13)$ & $-.9063(2.88)$ \\
Slovenia & $-.3267(3.63)$ & $-.4520(1.81)$ & $-.3963(4.18)$ & $-1.0324(3.68)$ \\
Spain & $-.5140(5.64)$ & $-.0447(0.17)$ & $-.6489(6.97)$ & $-.9923(3.57)$ \\
Sweden & $.9161(10.17)$ & $.5564(2.03)$ & $.8348(8.68)$ & $-.4314(1.31)$ \\
Turkey & $-1.4681(15.02)$ & $-1.1808(5.09)$ & $-1.4563(15.17)$ & $-1.5514(6.25)$ \\
UK & $.4153(4.90)$ & $.5122(2.09)$ & $.2853(3.08)$ & $-.3468(1.25)$ \\
West Germany & $-.2917(3.24)$ & $-.5151(2.01)$ & $-.2015(2.10)$ & $-.3791(1.33)$ \\
LR 3-4 & $-.0281(0.58)$ & $-.0082(0.06)$ & $-.0187(0.35)$ & $.0568(0.34)$ \\
LR 5-6 centre & $.0963(2.15)$ & $.1407(1.02)$ & $.0806(1.66)$ & $.1114(0.74)$ \\
LR 7-8 & $.1493(3.00)$ & $.1214(0.78)$ & $.1617(2.98)$ & $.2349(1.37)$ \\
LR right & $.4022(7.05)$ & $.5943(3.30)$ & $.3084(5.00)$ & $.4686(2.38)$ \\
LR n/a & $.0222(0.40)$ & $.4715(2.80)$ & $.0041(0.07)$ & $.1551(0.84)$ \\
LR dk & $-.0559(1.09)$ & $.2636(1.85)$ & $-.0874(1.54)$ & $-.0350(0.22)$ \\
/cut1 & -3.1719 & -3.2802 & -1.6555 & -2.0788 \\
/cut2 & -1.3181 & -1.5008 & .0266 & -.3943 \\
/cut3 & 1.8420 & 1.5636 & 2.9507 & 2.5476 \\
$\mathrm{~N}$ & 29,517 & 3655 & 24040 & 2800 \\
Pseudo R ${ }^{2}$ & .1472 & .1053 & .1511 & .1154
\end{tabular}

Notes: excluded categories - Belgium; Age Left school (ALS) <16; Left-right scale - left and single. All equations also include a further fourteen occupation dummies for the employed.

Q1. On the whole are you not at all satisfied; not very satisfied; fairly satisfied or very satisfied with the life you lead? Q2. How would you judge the current situation in each of the following? Your personal job situation - very bad; rather bad; rather good or very good. T-statistics in parentheses.

Source: Eurobarometer \#71.1, January-February 2009 
Table 12. Life satisfaction, United States, 2008 (ordered logits)

\begin{tabular}{|c|c|c|c|c|}
\hline & All ages & Ages 18-24 & All ages & Ages 18-24 \\
\hline $15-24$ years & $4052(18.07)$ & & . $4652(20.59)$ & \\
\hline $25-34$ years & $.0912(7.16)$ & & $1660(12.90)$ & \\
\hline -44 years & $.0099(0.91)$ & & $.0180(1.65)$ & \\
\hline -64 years & $.2036(20.06)$ & & .2361 (23.08) & \\
\hline + years & $.3185(25.86)$ & & .4283 (34.24) & \\
\hline $5-24 *$ unemployed & $.3588(5.98)$ & & $.2350(3.90)$ & \\
\hline Tale & -.0879 (12.69) & $.1519(4.16)$ & $-.1333(19.02)$ & $.1160(3.15)$ \\
\hline nemployed & $-.9683(53.28)$ & $-.5011(8.19)$ & $-.7469(40.46)$ & $-.4576(7.41)$ \\
\hline Self employed & $.0901(7.59)$ & $-.0951(1.05)$ & $.1174(9.81)$ & $-.1057(1.17)$ \\
\hline omemaker & $.0202(1.56)$ & $.1582(1.95)$ & $.0964(7.30)$ & $.1934(2.37)$ \\
\hline tudent & $.0351(1.27)$ & .2915 (6.88) & $.1150(4.13)$ & $.2666(6.20)$ \\
\hline etired & $.0036(0.33)$ & $.4330(0.93)$ & .1209 (10.76) & $.3933(0.84)$ \\
\hline Disabled & $1.3051(85.80)$ & -.9282( & $-1.0384(65.58)$ & $-.8390(6.24)$ \\
\hline Black & $-.0010(0.08)$ & $-.2767(4.46)$ & .0866 (6.51) & $3.06)$ \\
\hline Asian & -.307 & -.5877 & -.2511 & ..69) \\
\hline Haw & -.1351 & -.12 & -.0949 & 31) \\
\hline merican & -.0380 & -.36 & .0747 & .49) \\
\hline Other & -.1647( & -.150 & $-.1038(2$. & -.117 \\
\hline Multi-race & $-.1994(7.55)$ & $-.4291(3.92)$ & $-.1499(5.65)$ & $-.4003(3.65)$ \\
\hline ispa & $-.0233(1.56)$ & -.1429 & $.1202(7.92)$ & $-.0541(0.94)$ \\
\hline cho & $-.0522(0$. & -.232 & $.0152(0.2)$ & $0.38)$ \\
\hline g Grades 9-11 & $-.0271(0.3)$ & -.259 & $.0155(0.20)$ & $(0.57)$ \\
\hline High school graduate & $.1667(2.19)$ & $-.0772(0.19)$ & . $1283(1.67)$ & $-.0692(0.17)$ \\
\hline 1-3yrs college & $.2830(3.71)$ & $.1098(0.27)$ & $.1567(2.04)$ & $.0756(0.18)$ \\
\hline College graduate & $.6481(8.50)$ & $.5422(1.31)$ & $.3691(4.80)$ & $.4436(1.07)$ \\
\hline Schooling n/a & .2791 (2.49) & $.4414(0.63)$ & . 1465 (1.30) & $.3553(0.51)$ \\
\hline Divol & -.8142( & -.80 & -.5925 & -.75 \\
\hline Wid & -.633 & -1.03 & -.4619 & -.99 \\
\hline Separated & $-1.0393(44.38)$ & -.8547 & $-.8093(34.17)$ & $-.8032(4.64)$ \\
\hline Single & $-.8293(72.61)$ & $-.4228(7.94)$ & $-.6096(51.82)$ & $-.3991(7.36)$ \\
\hline Living as married & $-.5801(26.19)$ & $-.4149(5.67)$ & $-.4539(20.33)$ & $-.3747(5.08)$ \\
\hline Year2 & $-.0337(0.61)$ & $.4770(2.07)$ & $-.0490(0.88)$ & $.4662(2.02)$ \\
\hline /cut1 & -4.8912 & -5.3989 & -4.2766 & -5.1012 \\
\hline /cut2 & -3.1857 & -3.5090 & -2.5643 & -3.2092 \\
\hline /cut3 & .1052 & -.1443 & .7645 & .1742 \\
\hline Income dummies & - & - & 9 & 9 \\
\hline $\mathrm{N}$ & 396,794 & 13,544 & 396,793 & 13,544 \\
\hline Pseudo $\mathrm{R}^{2}$ & .0561 & .0322 & .0660 & .0373 \\
\hline
\end{tabular}

Notes: all equations include 50 state dummies plus Guam, Puerto Rico and US Virgin Islands. Excluded categories ages 45-54; wage worker and no schooling Source: Behavioral Risk Factor Surveillance System Survey (BRFSS), 2008. Q. In general, how satisfied are you with your life? Very dissatisfied; dissatisfied; satisfied or very satisfied. T-statistics in parentheses. 


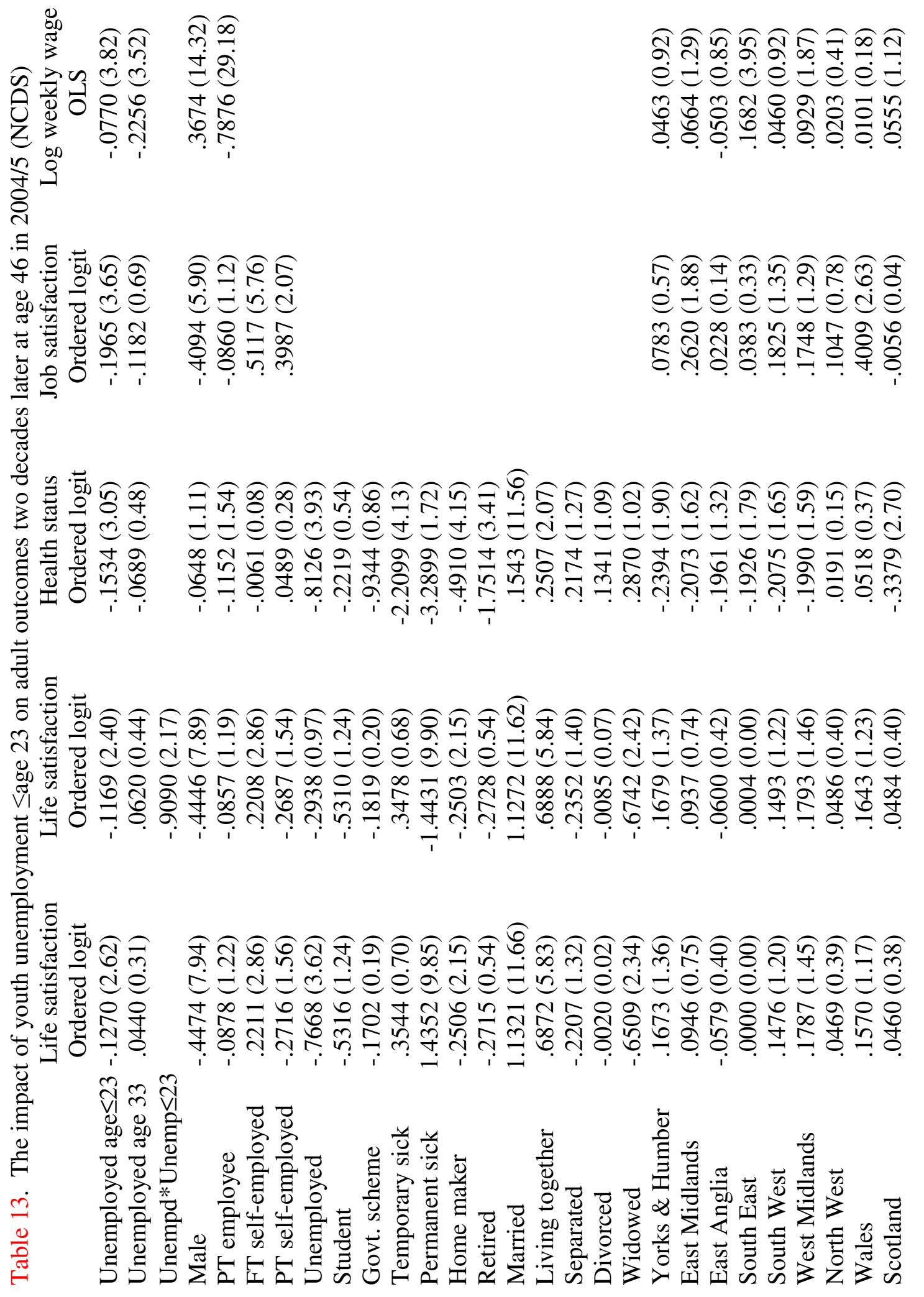




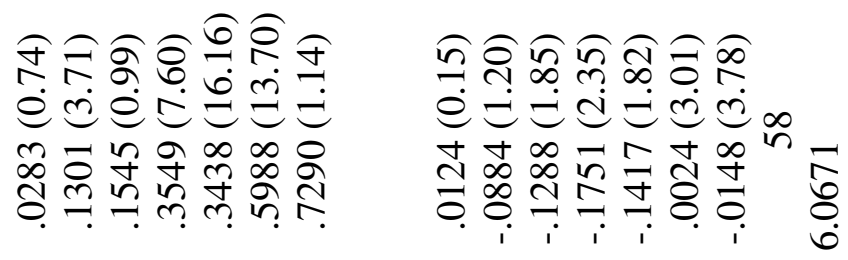

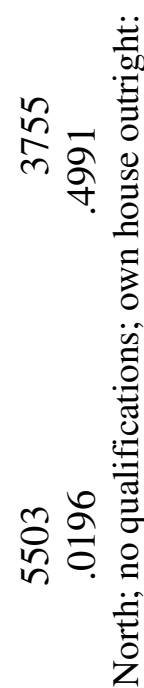

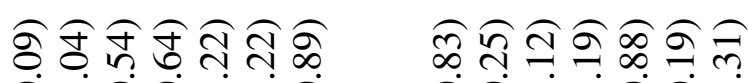

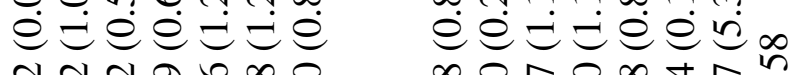

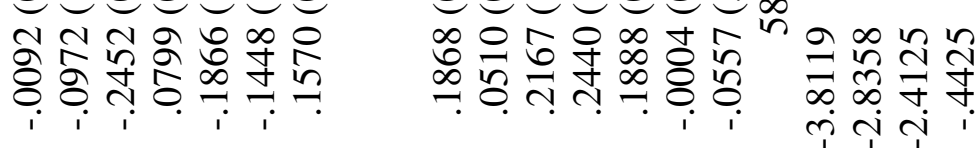

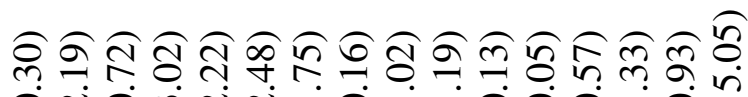

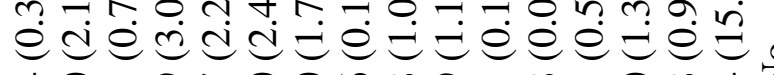

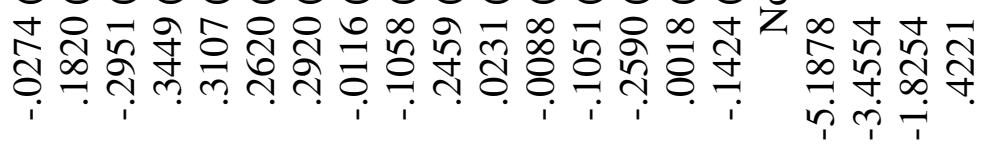

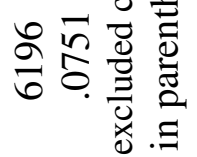

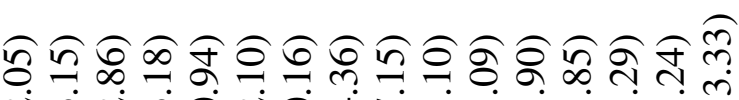

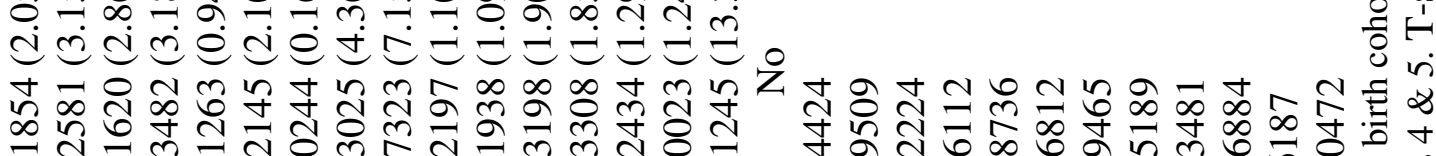

i

2

웅

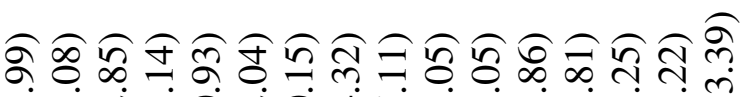

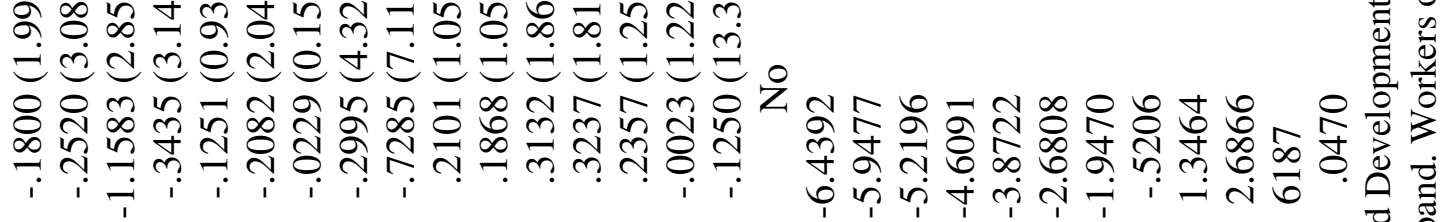

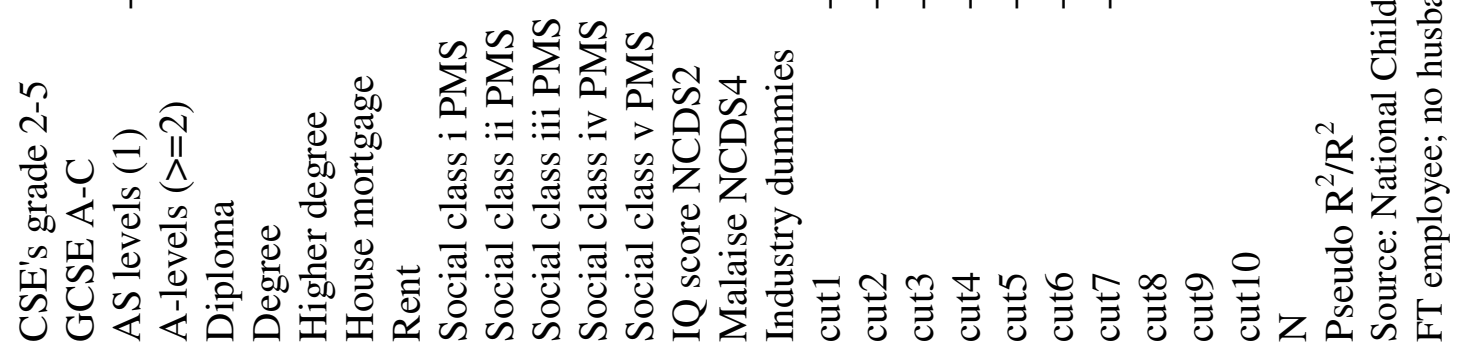




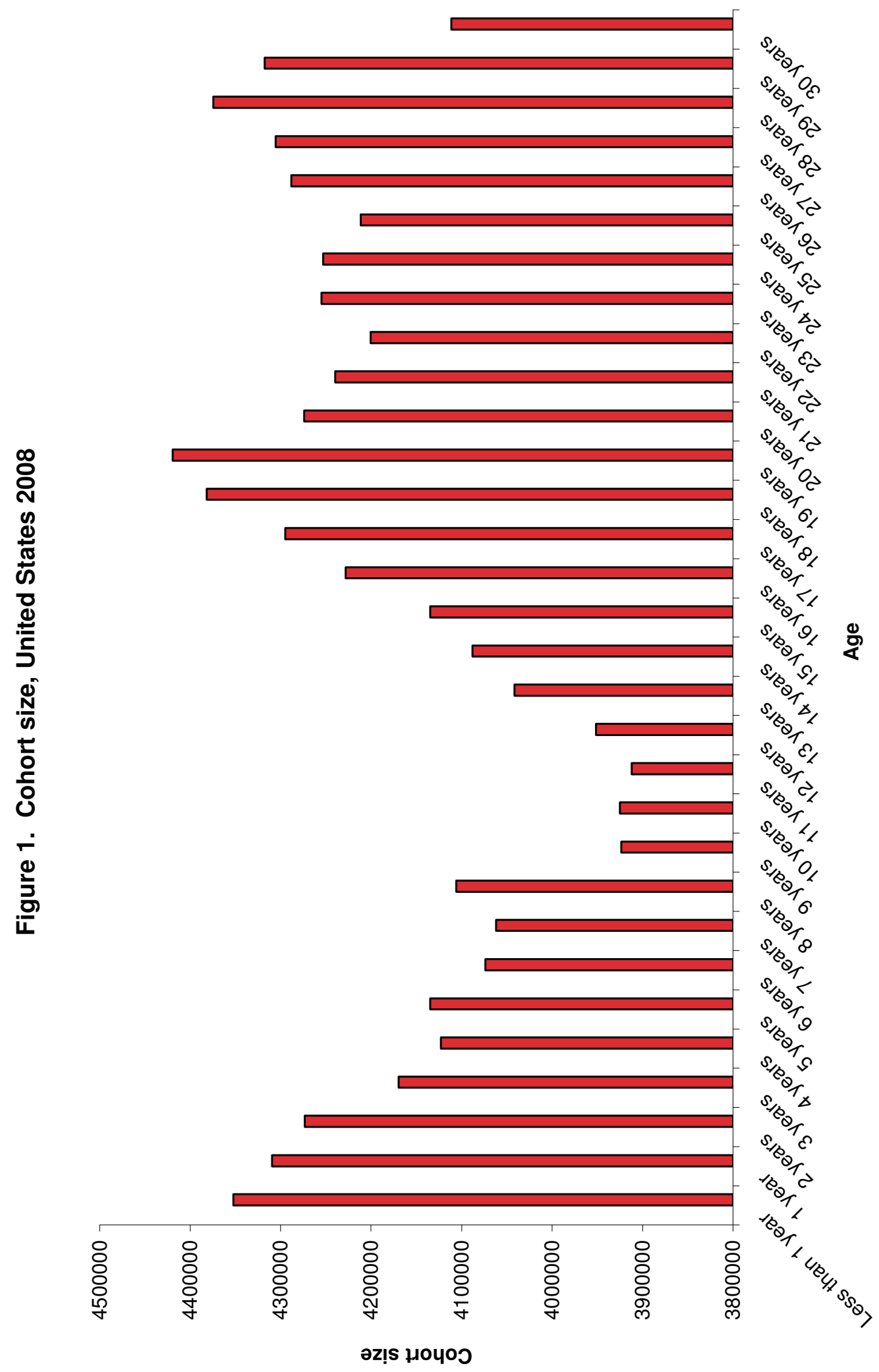




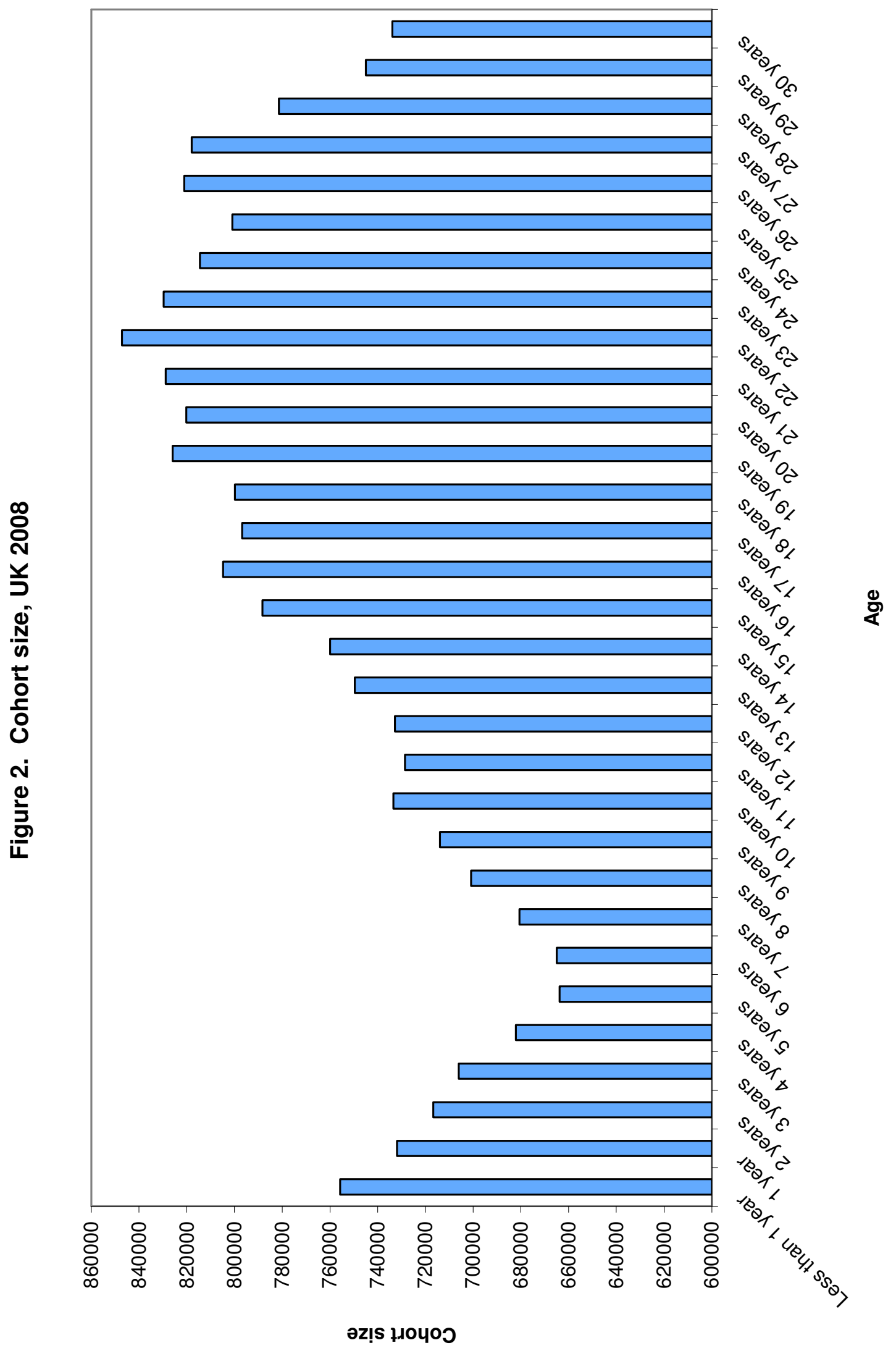




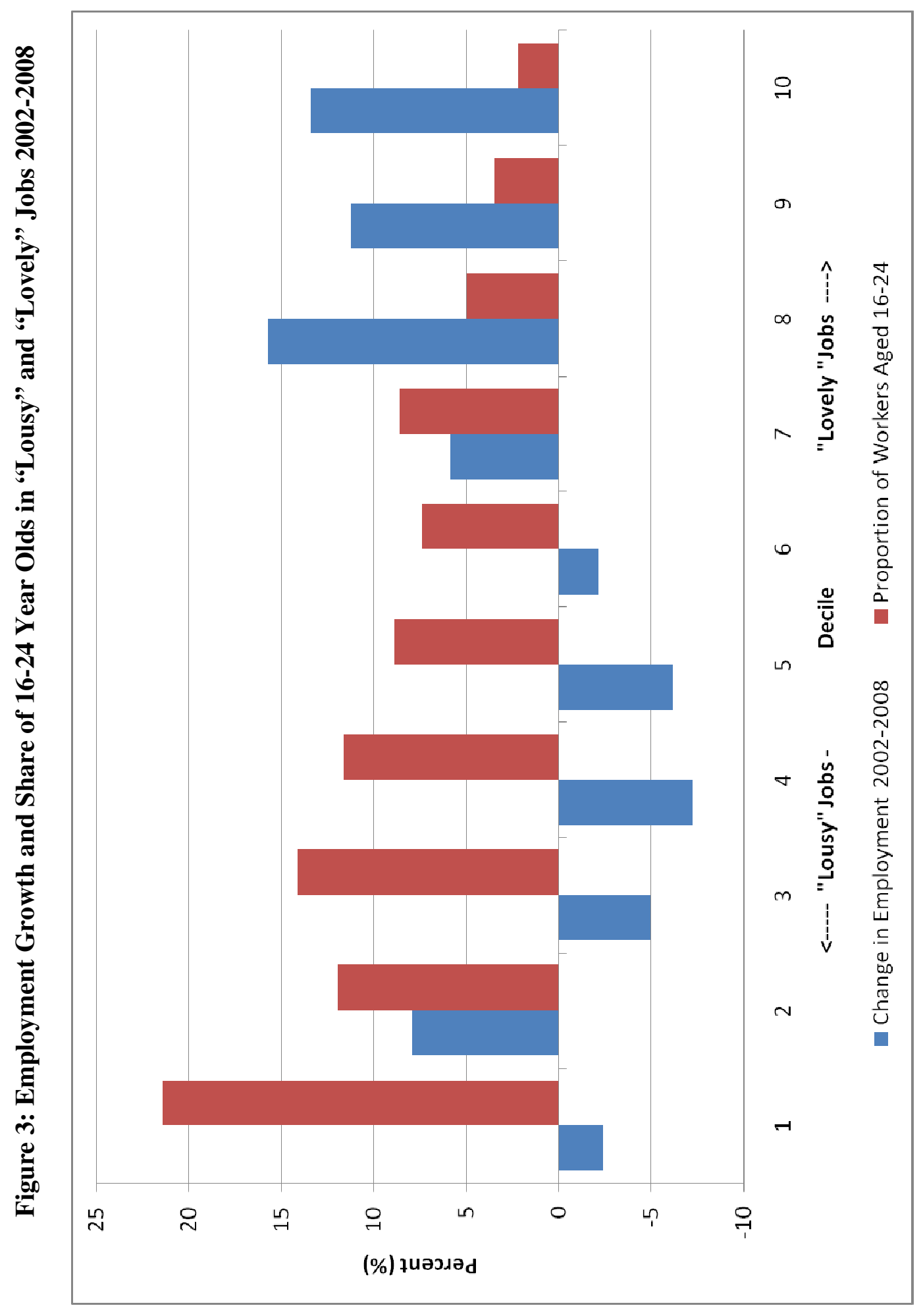

